\title{
ADOLESCENT DATING VIOLENCE
}

by

Joann Schladale

\begin{abstract}
Thesis submitted to the Faculty of the Virginia Polytechnic Institute and State University

in partial fulfillment of the requirements

for the degree of

MASTER OF SCIENCE

in
\end{abstract}

Family and Child Development

APPROVED :
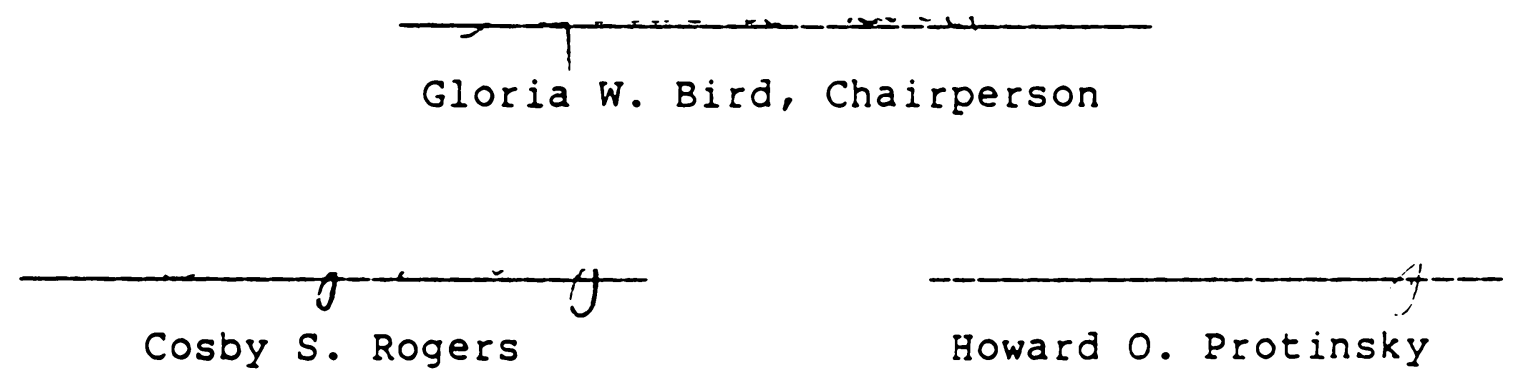

August, 1987

Blacksburg, Virignia 


\author{
ADOLESCENT DATING VIOLENCE \\ by \\ Joann Schladale \\ Gloria W. Bird, Chair \\ Family and Child Development
}

(ABSTRACT)

Dating relationships were examined for a sample of 156 female and 124 male college freshman. Comparison of self esteem, mastery, coping strategies, and negotiation styles were made between those who had experienced dating violence and those who had not. A theoretical framework based on the resource aspect of exchange theory is used to frame the study. Factor analysis was used to identify coping strategies and negotiation styles. Discriminate analysis was used to determine the discriminating power of the independent variables. Findings indicate that the negotiation style of Negative Affect and the coping strategies of Confrontation and Social Support discriminate between violent and nonviolent group membership. 


\section{ACKNOWLEDGEMENTS}

I would like to express my sincere appreciation to my committee Gloria Bird, Cosby Rogers, and Bud Protinsky for their enthusiastic support and assistance. Gloria has provided unwavering sustenance, humor, and a true sense of camaraderie which have greatly enhanced my learning experience. Her faith in my abilities has enabled the accomplishment of goals previously considered unattainable. For this I am very grateful.

I also wish to thank the study group who have shared laughter, tears, and many pizzas:

$$
\text { - and }
$$

superb knowledge of statistics guided me through discriminate analysis. The Family and Child Development staff,

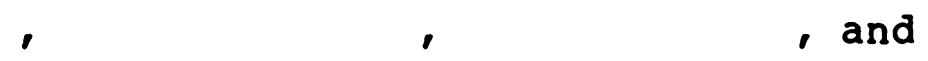

provided cheerful and never-ending patience and encouragement.

Above all else, the support and love (in addition to the housekeeping and parenting) of my husband, - have sustained me throughout this endeavor. My son, - has exhibited amazing tolerance and provided invaluable joy that fills my heart! 


\section{TABLE OF CONTENTS}

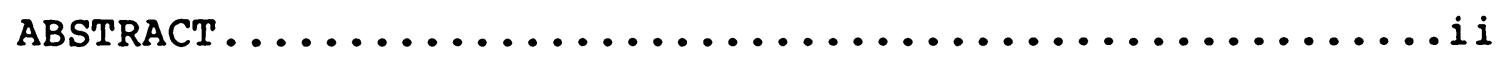

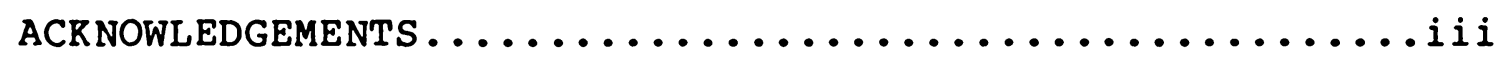

INTRODUCTION . . . . . . . . . . . . . . . . . . . .

THEORETICAL FRAMEWORK $\ldots \ldots \ldots \ldots \ldots \ldots \ldots \ldots \ldots \ldots \ldots \ldots \ldots \ldots \ldots$

REVIEW OF LITERATURE.....................

Self Esteem.........................

Mastery............................

Coping Strategies....................

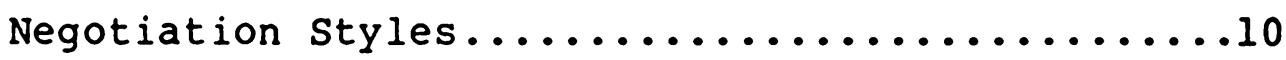

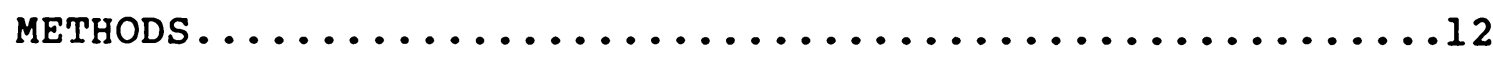

Sample...........................

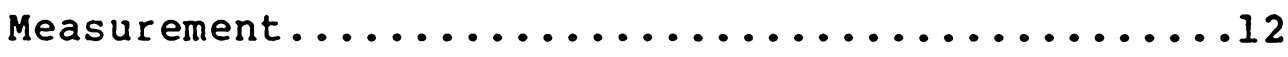

Data Analysis........................ 44

RESULTS.............................

SUMMARY AND DISCUSSION.....................

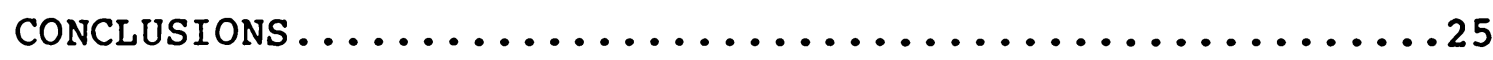

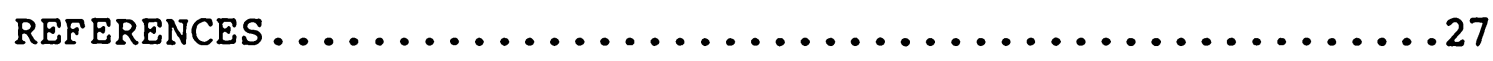

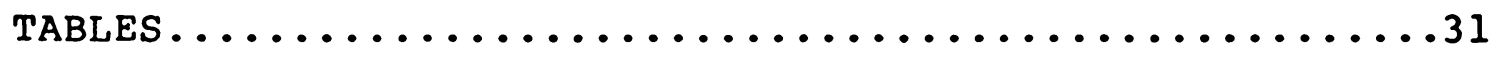

APPENDICES ..........................

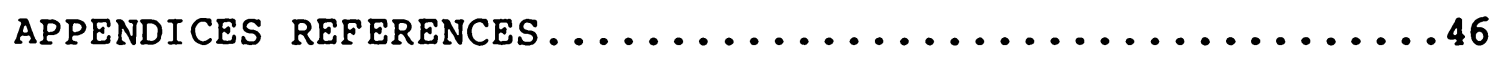

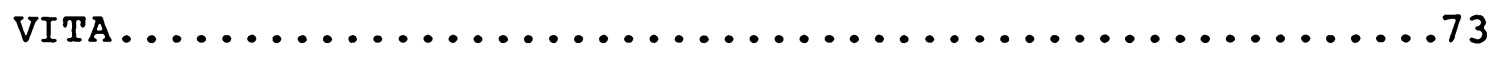




\section{LIST OF APPENDICES}

Page

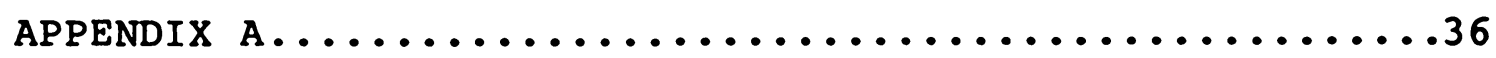

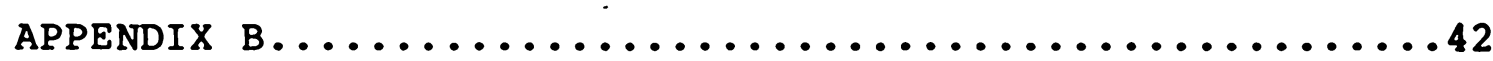

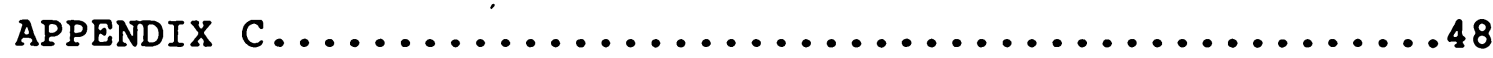

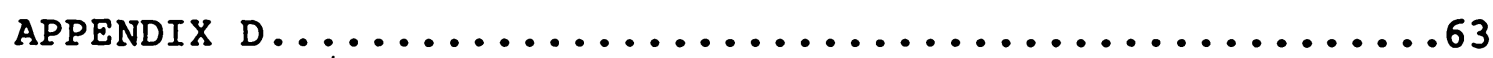

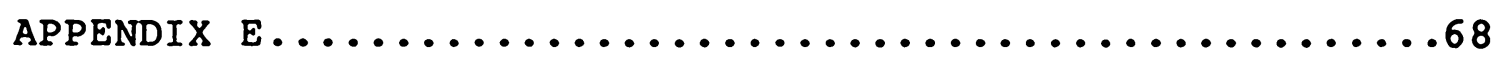




\section{LIST OF TABLES}

Page

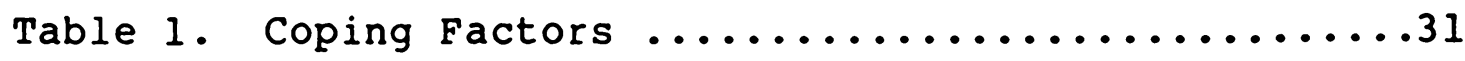

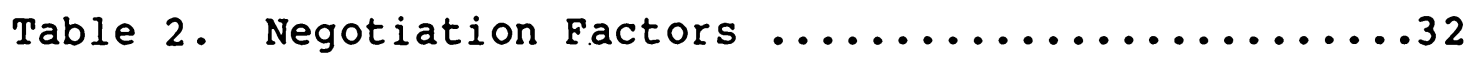

Table 3. Group Means and Standard Deviations ........33

Table 4. Stepwise selection: Summary ...................

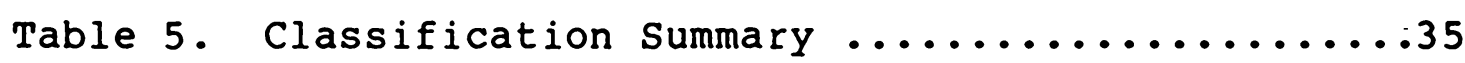

Table 6. Factor Analysis of Coping Items ..........69

Table 7. Factor Analysis of Negotiation Items ......72 


\section{Introduction}

It is only during the past six years that research has begun to materialize on the issue of adolescent dating violence. Studies indicate that a substantial number of high school and college students experience various forms and levels of violence in their courtship experiences (Cate, Henton, Roval, Christopher, \& Lloyd, 1982; Laner \& Thompson, 1982; Makepeace, 1981). Of those who are participants in dating violence, research indicates that between 398 and 548 maintain ongoing relationships despite experienced abuse (Bogal-Allbritten \& Allbritten, 1985; Matthews, 1984; Sigelman, Berry, \& Wiles, 1984). The purpose of this study is to extend prior research by exploring factors that distinguish between adolescents who experience no violence in dating relationships and adolescents who maintain dating relationships despite incidences of violence. Differences in self-esteem, mastery, use of coping strategies, and choice of negotiation styles will be examined. 


\section{THEORETICAL FRAMEWORR}

For the purposes of this study, violence is described as an actual physical altercation with or without injury (Walker, 19.84). Various theoretical frameworks have been used to explain courtship violence. Laner and Thompson (1982) present the most in-depth approach by integrating concepts of conflict and exchange theories in conjunction with cultural influences such as tolerance for and acceptance of violent behavior. This framework is implicit in much of the literature.

In keeping with previous research, the present study incorporates the resource aspects of social-exchange theory into its description of maintenance in abusive and nonabusive dating relationships. Gelles and Straus (1979), summarizing the distinctive contributions of selected theories of violence, maintain that an individual's range of available resources illustrates situations in which violence may be used, i.e. when other resources are inadequate. Self-esteem, mastery, use of coping strategies and choice of negotiation style are viewed as resources that each dating partner brings to the relationship. More specifically, self-esteem and mastery are described as psychological resources that mediate the negative consequences of life strains, in this case relationship violence (Pearlin \& Schooler, 1978). Abusive 
acts in dating relationships most likely function to increase vulnerability by confronting partners with "evidence of their own failures--or lack of success--and with inescapable proof of their inability to alter the unwanted circumstances of their lives" (Pearlin, Lieberman, Menaghan, \& Mullan, 1981, p. 340). For this study, remaining in an abusive relationship is expected to correlate with lower self-esteem and less of a sense of being in control of life situations.

Coping is also considered a resource. Typically, people facing a problem or life strain react by making an effort to cope by changing the problematic situation or by controlling the interpretation or meaning of the problematic situation (Lazarus \& Folkman, 1984; Pearlin \& Schooler, 1978). The manner in which a person copes with conflict in a dating relationship, for example, should be a resource that helps distinguish between adolescents in abusive and nonabusive relationships. Based on past empirical findings on coping (Pearlin \& Schooler, 1978) adolescents who use coping strategies that directly modify or change situations out of which relationship conflicts occur would seem less likely to be in abusive relationships. In addition, these adolescents are expected to use a wider range of coping responses. 
Power has also been identified as a resource in the literature on close relationships (Goode, 1971). One person's ability to influence the behavior of another is often described as power (Falbo, 1977). However, Scanzoni and Szinovacz (1980) describe power as "successfully accomplishing or resisting changes" (p. 101). They view negotiation as part of the decision making process when one or both partners are "trying to negotiate a resolution to some opposition" (p. 64). This project was conducted in order to identify the negotiation styles and, based on the findings of Falbo and Peplau (1980), it was expected that individual negotiation style will differentiate between adolescents in nonabusive and abusive dating relationships. Young people in nonviolent dating relationships will most likely utilize direct bilateral negotiation styles which include bargaining, reasoning, being persistent, discussing and compromising (Falbo \& Peplau, 1980). 
REVIEW OF LITERATURE

Makepeace (1981) in a ground-breaking study, discovered that 218 of participants acknowledged having at least one personal experience involving violence with a dating partner. Since then researchers using varying definitions of courtship violence have estimated that between 128 and 658 of dating couples engage in some form of violent behavior (Bernard \& Bernard, 1983; BogalAllbritten \& Allbritten, 1985; Lane \& Gwartney-Gibbs, 1985; Laner \& Thompson, 1982; Matthews, 1981; O'Reefe, Brockopp, \& Chew, 1986; Sigelman et al., 1984). Though researchers such as Sigelman et al. (1984) indicate that 538 of males and 528 of females acknowledge involvement in abusive acts during a dating relationship; the majority of studies found that approximately one-fourth of young people in dating relationships experience violent episodes (Bernard\& Bernard, 1983; Cate et al., 1982; Laner \& Thompson, 1982).

Differences in definition, measurement and sample selection may account for the varying incidence rates reported. For example, Lane and Gwartney-Gibbs (1985) include "acquaintances, friends, partners, and dates" ( $p$. $57)$ in their operational definition of participants in courtship violence while Laner and Thompson (1982) and O'Reefe, et al. (1986) include verbal abuse as well as physical abuse in their definitions. Differences are also 
apparent in the samples chosen for research. Only two available studies involved high-school-aged populations and investigations focusing on college students indicate relatively wide age ranges in their samples.

Past research reveals that a substantial number of young men and women choose to remain in abusive relationships. However, only Roval and Lloyd (1986), in an unpublished paper, attempted to ascertain "characteristics of abusive or abused partners' ongoing relationships" ( $p$. 3).

This investigation expanded research in the area of dating violence by identifying points of similarity and contrast between two groups of adolescents, those who have experienced violent dating relationships and those who have not, controlling for age range, living arrangements, and education level.

Independent Variables

Self-Esteem. Examining resources that possibly affect participation in abusive dating relationships is of paramount importance in understanding the incidence of courtship violence. Sanford (1980) maintains that self-esteem is the primary resource required for selfprotection. Low self-esteem increases the probability of experiencing violence during adolescence (Kaplan, 1972). A poor self-image promotes the inability to terminate a violent relationship through feelings of helplessness; 
feeling deserving of the abuse; and acceptance of violence as normative behavior (Gelles \& Straus, 1979; Walker, $1984)$.

There is a discrepancy in the literature about the relationship between self-esteem and courtship violence. Whereas Makepeace (1987) maintained that self-esteem is not a determinant of involvement in violent relationships, Deal \& Smith-Wampler (1986) concluded that it is a significant predictor of participation in courtship abuse. Lenore Walker in her research concerning battered women has also observed discrepancies regarding this variable. In 1979 she concluded that self-esteem was significantly related to the occurrence of spouse abuse. She later reported opposite results (1984) and stated that "this finding of a positive self-image is unusual and inconsistent with current theories about battered women" (Walker, p.80). It is therefore important to study self-esteem as it relates to adolescent dating violence in order to reach a clearer understanding (Laner, 1983).

Mastery. Personal control is also viewed as a psychological resource that could affect participation in abusive relationships. Generalized beliefs regarding mastery concern, in part, the extent to which people feel that they can control outcomes of importance (Pearlin \& Schooler, 1978). A person's interpretation of an event is an important factor in assessing mastery. According to 
Folkman (1984), cognitive appraisal processes are used to determine the meaning and relevancy of specific experiences as they relate to a personal sense of well-being. She maintains that "the greater the appraised threat in a situation, the more meaningful controlability will be" ( $p$. 842). Therefore, if the potential for harm during the course of an altercation is considered relevant to the individual's well-being, the importance of being able to control the outcome of such an event will be greater. Application of this concept to a violent dating partnership indicates that mastery plays an important part in the ability to terminate an abusive relationship. Bandura (1977) asserted that situational appraisals of control "determine... how long [a person] will persist in the face of obstacles and aversive experiences" (p. 80). Walker (1984) elaborates on a theory of learned helplessness, as originally proposed by Seligman (1975), which hinders the ability to affect positive control over life experiences ( $p, 2)$. No other studies reviewed for this project included mastery as a resource. It is therefore important to study this variable in an effort to understand the influence it may have on personal acceptance of participation in courtship violence.

Coping strategies. Makepeace (1981) suggested that stresses and strains exceed the coping abilities of those who participate in dating violence which results in 
eruptions of aggression and violence. Coping, as defined by Pearlin and Schooler (1978), "refers to behavior that protects people from being psychologically harmed by problematic social experience" (p. 2). Strategies used by adolescents to cope with courtship conflict or abuse have never been studied. Analysis of these strategies could provide important insight into the interactional patterns of abusive dating partners. Those efforts used to master, reduce, or tolerate pressure created by stress (Folkman, 1984) are key variables potentially indicating a susceptibility towards violent interaction. Piug (1984) maintained that college couples who abuse one another deal inadequately with relationship stresses. Perception of violence as a acceptable component of conflict management may enable definition of abuse as love in an attempt to explain why the violence has occurred (Henton et al., 1983). Violence is also viewed as normative behavior which may allow dating partners to tolerate violence without suffering undue stress.

Selective ignorance, or an attempt to highlight attention on positive or rewarding aspects of a situation, denial, passive acceptance, withdrawal, magical thinking, blind faith, and belief that the problem will go away are ali considered strategies for managing stressors (Pearlin \& Schooler, 1978). This type of cognitive restructuring functions to regulate emotions or distress and is 
considered emotion-focused coping. Problem-focused coping refers to strategies such as problem solving, decision making, and/or direct action (Folkman, 1984). Folkman maintained that successful problem-focused efforts depend primarily on the success of emotion-focused efforts. If a young person perceives violence as a manifestation of love, or normative behavior, little effort will be made to utilize problem-focused coping strategies aimed at eliminating violence. It is therefore important to assess the different coping strategies used by adolescents in violent and non-violent dating relationships.

Negotiation styles. Strategies used to influence decision making in the presence of implicit or explicit opposition as defined by Falbo and Peplau (1980) are a) direct-bilateral: negotiating, compromising; b) direct unilateral: stating needs, asking; c) indirect-bilateral: smiling, being affectionate and d) indirect-unilateral: pouting, remaining silent. Direct-bilateral strategies are seen as positive as these styles are considered more inclusive of a partner in the decision-making process. Use of indirect-unilateral negotiation styles are considered evasive, one-sided, and therefore negative (Falbo, 1977; Falbo \& Peplau, 1980).

yllo and Straus (1981) in an article concerning violence among married and cohabitating couples maintain that nonviolent skills for conflict management, such as 
discussion and negotiation, are essential components of intimate relationships. Laner (1983) pointed out that these skills are lacking in couples who are involved in dating violence.

Koval and Lloyd (1986) found that individuals who maintained abusive dating relationships reportedly utilized indirect-unilateral power strategies. These strategies do not require a partner's cooperation and are used when the goal is important and non-compliance is expected (Falbo \& Peplau, 1980). Falk (1977) asserted that men who batter lack the skills and self-confidence needed to ask for what they want in a nonthreatening manner. Since Koval and Lloyd's is the only study investigating negotiation styles, further study is justified in order to establish accuracy of predictability.

In order to fully understand the dynamics of courtship violence, research must consider the context in which it occurs. Self-esteem, mastery, use of coping strategies, and choice of negotiation styles are all resources empirically or theoretically connected to the ability or inability to eliminate violence in dating partnerships. Investigation of the relationships among these various factors will enhance knowledge concerning adolescent dating violence in an effort to better understand this phenomenon. 


\section{METHODOLOGY}

Sample

Data were collected from a random sample of 300 female and 300 male college freshman living in campus dormitories at Virginia Tech $(\underline{N}=600)$. This selection procedure was chosen in order to limit the study to adolescent dating relationships, diminish the number of cohabitating couples and reduce age variation in the sample. Four hundred and one individuals responded, indicating a 678 response rate. One hundred and seventeen participants were considered ineligible due to lack of a serious dating partner. The majority (968) of the participants were 18 and 19 years old. Of the students who responded, 568 (156) were female, 448 (124) were male, 948 were white, 28 were black, and 48 reported other racial backgrounds.

Measurement

Rosenberg's (1965) Self-Esteem Scale was used to assess self-esteem. Participants responded to the 10-item instrument on a seven-point Likert-type response scale ranging from 1 (Strongly Disagree) to 7 (Strongly Agree). The scale is a well-validated measure of self-esteem (McCarthy \& Hoge, 1982). Past research found that test-retest reliability was .85 , reproducibility was 928 , 
and scalability was 728 (Silber \& Tippett, 1965; Simons \& Murphy, 1985).

A modified version of the Conflict Tactics Scale (Straus, 1979) was used to determine degree of relationship violence. This 10-item instrument includes a five-point Likert-type response scale ranging from 1 (Threatened only) to 5 (Frequently Done). Reliability was established through the use of item-to-total correlation and average intercorrelation (Straus, 1979). Validity was determined in a number of analyses as this scale is universally used in the study of violent relationships (Bullcroft \& Straus, 1975; Steinmetz, 1977b).

Items assessing the use of coping strategies were from the Ways of Coping Inventory (Lazarus \& Folkman, 1984). The 41 items include a seven-point Likert-type response scale ranging from 1 (Never) to 7 (Always). Folkman and Lazarus (1980) established reliability at .80 (Chronbach's alpha).

Negotiation styles were measured by the Power Strategies Scale (Falbo, 1982) supplemented with items suggested by Scanzoni (1978). Participants were asked to respond to 23 items using a seven-point Likert-type response scale ranging from 1 (Never) to 7 (Always). Reliabilities for all strategies were above .80 and were established by Falbo and Peplau (1980) based on a computational formula outlined by winter (1973). 
Demographic items include: age, gender, dating status, employment and income status of parents, in addition to other personal data.

Data Analysis

Frequency distributions, means, and standard deviations were computed for each variable. A correlation matrix was generated for initial inspection and factor analysis was used to identify coping strategies and negotiation styles. Finally, discriminate analysis (multiple regression with a dichotomous dependent variable) was implemented to determine differences in personal and relationship characteristics between adolescents in nonabusive dating relationships and adolescents in abusive relationships. This discriminate procedure results in a forecasting function, where the objective is to predict group membership, and an evaluative function which is comparable to the $F$ test of the $R^{2}$ in a typical multiple regression. 
RESULTS

Incidence

Thirty-four percent of respondents self-reported the following violent experiences: pushed, shoved, grabbed (178), slapped (148), wrestled or pinned down (78), threw an object at $(6 \%)$, punched with fist (48), clawed, scratched, bit $(38)$, or kicked (38). One respondent indicated abuse using a lethal weapon. The responses were similar for those reporting violence perpetrated by their dating partners: pushed, shoved, grabbed (208), slapped (158), threw an object at (98), wrestled or pinned down (78), clawed scratched, bit (68), punched with fist (58), kicked (58), or hit with object (48). Three respondents indicated abuse with a lethal weapon.

Respondents who had experienced courtship violence indicated that their partners initiated physical abuse 518 of the time while they initiated the abuse 418 of the time. The remaining 88 reported that both partners were equally responsible for initiating violent altercations. When the partner initiated violence, respondents indicated that they either tried to get away (138), protected themselves (188), or fought back (208). If they initiated the abuse, their partner tried to get away (98), protected themselves (188), or fought back (148). 
In 1979, Lenore Walker proposed a cycle of violence theory outlining a sequential, circular pattern consisting of three stages associated with recurrent interpersonal violence in intimate relationships. These stages: tension building; acute battering; and loving contrition outline salient phases in the abusive relationship. When asked, "Does this illustration represent the pattern of how physical arguments occur in your dating relationship?", 538 of respondents who had experienced courtship violence identified it as the predominant pattern of physical abuse. Thirty-two percent were "Not Sure", and 158 said "No" and indicated a different pattern.

Results indicated that abuse was most likely to occur after the relationship had progressed to serious dating (818). Sixteen percent of participants in violent dating partnerships reported that the relationship got worse after an incident of violence. Fifty-one percent indicated no change and 338 maintained that the relationship improved. For 938 of the respondents experiencing dating violence, the first incident of courtship abuse occurred between the ages of 15 and 18, and 318 of these respondents had experienced violence with more than one dating partner. The most common sources of physical arguments was jealousy over involvement, or perceived involvement, with another person (518) and sexual pressure (108). Thirty-five percent reported other sources 
of physical arguments including rough play, frustrations from daily living, or petty arguments that evolved into abusive interaction. The least likely reason given for a violent altercation was the use of alcohol or drugs (18). Participants were asked to identify feelings resulting from physical arguments with their dating partners. Sorrow (548), loss of control (518), hurt (448), anger (418), and guilt (398) were the predominant responses. Seldom did anyone involved in courtship violence identify feelings of gladness (68), satisfaction (78), or worthlessness (78).

Factor Analysis

Factor analysis of coping strategies resulted in the identification of eight factors: Denial/Distancing; Accepting Responsibility; Problem Solving; Confrontation; Social Support; Spiritual Belief/Fantasy; Self-Control; and Escape. Five negotiation styles were identified: Negative Affect; Direct Appeal; Bargaining/Compromise; Ultimate Effort; and Indirect Appeal.

The type of factor analysis used was principal factoring with iteration. This method of analysis extracts the number of factors with eigenvalues greater than or equal to 1.0. The varimax technique was used to rotate the axis orthogonally. The resulting factors are described as dimensions or categories of the variables to be studied. 
Discriminate Analysis

Initial results of the discriminate analysis revealed that $186(668)$ of the respondents were classified as nonviolent and 94 (348) were violent. Table 3 illustrates the means and standard deviations computed for coping strategies, negotiation styles, mastery, and selfesteem by group. For both groups the most frequently used strategies for coping with relationship stress were selfControl and Accepting Responsibility. Respondents in both groups were least likely to use Escape/Avoidance responses. The most frequently utilized negotiation styles included Bargaining/Compromise and Direct Appeal. Negative Affect and Ultimate Effort were used least frequently.

Table 3 About Here

A discriminate analysis was computed to assess whether the variables included in the study enable correct classification of group membership in either the nonviolent or violent category. Prior probabilities were based on the initial results of the discriminate analysis on the sample in which nonviolent membership was 668 and violent membership was 348 . A pooled covariance matrix was 
utilized because the test of homogeneity of within covariance matrices yielded an observed $\mathrm{Chi}$ square $=$ 129.43, $\underline{\mathrm{df}}=120, \mathrm{p}$-value $=.26$. This was calculated by dividing the total number of correct classifications by the total number of responses. Correct classification for the nonviolent group was equal to $898(\underline{\underline{N}}=162)$ whereas correct classification for violent group membership equaled 318 $(\underline{N}=29)($ Table 5$)$. Correct classification overall occurred for 708 of the respondents.

Finally, a stepwise discriminate analysis was computed to determine which, if any, of the variables better discriminated between violent and nonviolent dating behavior. Negative Affect, Social Support, and Confrontation were found to be significantly related to group membership. In response to relationship conflict, respondents in the violent group relied significantly more often on negotiation styles based on Negative Affect, such as insulting or being especially disagreeable. They were also significantly more likely to confront and blame dating partners. Conversely, those who coped by seeking social support such as asking a friend or relative for advice were significantly less likely to be involved in violent dating relationships. 
Tables 4 and 5 About Here

Mastery and self-esteem did not discriminate between violent and nonviolent respondents. 
The present study indicates that 348 of participants experienced violence in a serious dating relationship. These findings are in accordance with previous research (Bernard \& Bernard, 1983; Lane \& Gwartney-Gibbs, 1985; O'Reefe et al., 1986). Responses illuminated important information concerning the process of physical arguments during courtship. Reciprocity during abusive altercations was exhibited as were interpersonal dynamics highlighting patterns of initiation of abuse and responses to the violent acts. Sequential patterns reported by respondents in abusive relationships were found to support Walker's (1979) cycle of violence theory.

Although participants in courtship abuse often felt sorry, hurt, angry, and/or guilty about the physical altercations their feelings of self-worth were apparently unaffected as only 78 reported strong feelings of worthlessness. This finding is reinforced by results of the discriminate analysis which indicated no evidence to support a significant relationship between self-esteem and maintenance of violent-free dating relationships. It may appear incongruous that individuals reporting a high level of self-esteem are just as likely to be involved in dating violence as those exhibiting a poorer self image. When young people accept violence as normative behavior and even 
maintain that the abuse signifies love in their intimate relationships, as cate et al. (1981) discovered, they are unlikely to display a negative self-image. In addition, Walker (1984) proposed that perserverance in a violent relationship may contribute to a positive sense of self worth through feelings of survival under adverse conditions. Another reason for these results may be that college students do not rely solely on dating relationships to maintain a sense of self-worth. Rewards from involvement in multiple roles, i.e. coursework, extra-curricular activities, and peer relationships, may account for similarity in self-esteem between both groups (Baruch, Barnett, \& Rivers, 1985).

Even though participants in courtship violence reported strong feelings of not being in control after violent interactions (518), these responses appear unrelated to global feelings of mastery. As with self-esteem a sense of mastery is multifaceted. College life necessitates independent thought and action requiring problem-solving and decision making. The dating relationship is but one component and, even when abusive, may not diminish feelings of personal control. This finding indicates that these respondents must not view the violence as a threat, potentially affecting their sense of well-being (Folkman, 1984). If, as mentioned previously, the physical arguments are considered normative, and if 
participants assume responsibility for their actions (as indicated by frequency of use of Accepting Responsibilities as a coping strategy), then their sense of mastery would parallel that of respondents who have not experienced courtship violence.

The discriminate analysis did indicate that negotiation styles based on Negative Affect and coping strategies utilizing Confrontation are significantly related to participation in adolescent dating violence. A young person who attempts to influence a dating partner's behavior by withdrawing, being especially disagreeable, insulting, or swearing is at greater risk of involvement in courtship violence. These results parallel Koval \& Lloyd's (1986), and support the hypothesis that young people in violent dating relationships are more likely to use indirect unilateral styles that do not require a partner's cooperation. Since high degrees of satisfaction are associated with the use of direct styles (Falbo \& Peplau, 1980), those utilizing indirect means of negotiation would most likely be less satisfied with the relationship and therefore more prone to disagreement and the potential for abuse.

Those who respond to relationship conflicts by expressing anger towards, and blaming their partner, in an effort to get their partner to change are also more inclined to participate in abusive dating relationships. 
Confrontational blaming is a coping strategy that does not modify or change a situation out of which relationship conflict occurs (Pearlin \& Schooler, 1978). Although Confrontation is a problem-focused coping strategy, the direct action it implies is based on blaming which is not conducive to successful problem-solving efforts (Folkman, 1984).

Those respondents who chose to cope with relationship stress by asking a friend or relative for advice, seeking sympathy and understanding from someone else, or bolstering their own morale in an effort to feel better about the stressful situation were more likely to be successful in avoiding physical altercations with their dating partners. This finding is in keeping with previous research showing that support does mitigate the effects of stress (Pearlin et al., 1981). The ability to communicate concerns to others about issues involving conflict in dating relationships illustrates the importance of social support as a resource in the prevention of interpersonal violence. 


\section{CONCLUSION}

Adolescent dating violence in the United States is a normal component of courtship behavior for many young people. The most recent studies indicate that increasing numbers of young adults are reporting experience with physical abuse in their intimate relationships (Deal \& Smith-Wampler, 1986 ; Makepeace, 1987).

This study adds to the literature information about what occurs during a physical argument between dating couples. The findings compliment and build on past research concerning the initiation of and response to acts of violence. Support is found for Walker's (1979) cycle of violence theory. In addition, evidence is provided that a theoretical framework integrating the resource aspects of social-exchange theory offers a useful rationale for the study of adolescent courtship violence.

Analysis of the data indicated that ways of coping with relationship conflict do discriminate between those young people who experience dating violence and those who maintain violent-free relationships. Strategies used for negotiatign relationship changes also differentiate between violent and nonviolent group membership.

This project focused primarily on personal characteristics and behavior that may account for involvement in courtship violence. We acknowledge the 
importance of integrating these findings into a more global explanation of courtship violence which should include the social context in which the violence occurs and address the dyadic nature of abusive interaction. 
Bandura, A. (1977). Social learning theory. Englewood Cliffs, New Jersey: Prentice Hall.

Baruch, G.R., Barnett, R.C., \& Rivers, C. (1985). Lifeprints: New_patterns of love and work for today's women. New York: Signet.

Bernard, M.L., \& Bernard, J.L. (1983). Violent intimacy: The family as a model for love relationships. Family Relations, 32, 283-286.

Bogal-Allbritten, R.B., \& Allbritten, W.L. (1985, May). The hidden victims: Courtship violence among college students. Journal of College student Personnel, 201-204.

Bullcroft, R. \& Straus, M. (1975). Validity of husband, wife, and child reports of intrafamily violence and power. University of New Hampshire, Family Violence Research Program, mimeographed paper V16.

Cate, R.M., Henton, J.M., Roval, J., Christopher, F.S., \& Lloyd, S. (1982). Premarital abuse: A social psychological perspective. Journal of Family Issues, 3, 79-90.

Deal, J., \& Smith Wampler, R. (1986). Dating violence: The primacy of previous experience. Journal of Social and Personal Relationships, 3, 457-471.

Falbo, T. (1977). Multidimensional scaling of power strategies. Journal of Personality and Social Psycholooy, 35, 537-547.

Falbo, T., \& Peplau, L.A. (1980). Power strategies in intimate relationships. Journal of Personality and Social_psychology, 388, 618-628.

Falbo, T. (1982). PAQ types and power strategies used in intimate relationships. Psychology of Women Quarterly, 6, 399-405.

Falk, M. (1977). Men who assault their wives. In M. Roy (Ed.), Battered women:_A_Psychosocial study of domestic_violence. New York: Van Nonstrand Reinhold. 
Folkman, S. (1984). Personal control and stress and coping processes: A theoretical analysis. Journal of Personality and Social Psychology, 46, 839-852.

Gelles, R.J., \& Straus, M.A. (1979). Determinants of violence in the family: toward a theoretical integration. In Burr, Hill, Nye, \& Reiss (Eds.), Contemporary theories about the family. New York: Free Press.

Goode, W.J. (1971). Force and violence in the family. Journal of Marriage and the Family, 33, 624-635.

Henton, J., Cate, R.M., Koval, J., Lloyd, S.A., \& Christopher, F.S. (1983). Romance and violence in dating relationships. Journal of Family Issues, 4, 467-482.

Raplan, H. (1972). Toward a general theory of psychosocial deviance: The case of aggressive behavior. Social Science and Medicine, 6, 593-617.

Koval, J.E., \& Lloyd, S.A. (1986). Premarital violence: Examining relationship factors as possible contributors. Paper presented at the National Council on Family Relations Annual Conference, Dearborn, Michigan, November 2-7, 1986.

Lane, R.E., \& Gwartney-Gibbs, P.A. (1985). Violence in the context of dating and sex. Journal of Family Issues, $6,45-59$.

Laner, M.R., \& Thompson, J. (1982). Abuse and aggression in courting couples. Deviant Behavior: An Interdisciplinary Journal, 3, 229-244.

Lazarus, R.S., \& Folkman, S. (1984). Stress__appraisal, and coping. New York: Springer.

McCarthy, J., \& Hoge, D. (1982). Analysis of age effects in longitudinal studies of adolescent self-esteem. Developmental 1 Psychology, 18, 372-379.

Makepeace, J.M. (1981). Courtship violence among college students. Family_Relations, 30, 97-102. 
Makepeace, J.M. (1987). Social factor and victim-offender differences in courtship violence. Family Relations, 36, 87-91.

Matthews, W.J. (1984). Violence in college couples. College student Journal, 18, 150-158.

O'Reefe, N.R., Brockopp, K., \& Chew, E. (1986, Nov-Dec). Teen dating violence. Social Work, 465-468.

Pearlin, L.I., \& Schooler, C. (1978). The structure of coping. Journal of Health_and Social Behavior, 19, $2-21$.

Pearlin, L.I., Menghan, E.G., Liberman, M.A., \& Mullan, J.T. (1981). The stress process. Journal of Health and Social Behavior, 22, 337-356.

Puig, A. (1984). Predomestic strife: A growing college counseling concern. Journal of College Student Personnel, 25, 268-269.

Rosenberg, M. (1965). Society and the adolescent self image. Princeton, NJ: Princeton University.

Sanford, L.T. (1980). The silent children. New York: Anchor.

Scanzoni, J. (1978). Sex-roles, women's work, and marital conflict. Lexington, MA: Lexington Books.

Scanzoni, J., \& Szinovacz, M. (1980). Family decision-making: A developmental sex-role model. Beverly Hills: Sage.

Seligman, M. (1975). Helplessness: On depression, development, and death. San Francisco: W.H. Freeman.

Sigelman, C.R., Berry, C.J., \& Wiles, R.A. (1984). Violence in college student's dating relationships. Journal_of Applied Social Psychology, 5, 530-548.

Silber, E., \& Tippett, J. (1965). In M. Rosenberg, Society and the a dolescent_self-image. Princeton: Princeton University Press. 
Simons, R., \& Murphy, P. (1985). Sex differences in the causes of adolescent suicidal ideation. Journal of Youth and Adolescence, 14, 423-434.

Sonkin, D., Martin, D., \& Walker, L. (1985). The male batterer. New York, Springer.

Steinmetz, S. (1977b). The cycle of violence: Assertive, aggressive, and abusive family interaction. New York : Praeger.

Straus, M. (1979). Measuring intrafamily conflict and violence: The conflict tactics scales. Journal of Marriage and the Family, 4l, 75-88.

Thompson, W.E. (1986). Courtship violence: Toward a conceptual understanding. Youth \& Society, 18, 162-176.

Walker, L. (1979). The_batttered woman. New York: Harper \& Rowe.

Walker, L.E. (1984). The battered_woman syndrome. New York: Springer.

Winter, D.G. (1973). The power motive. New York: Free Press.

Yllo, R. \& Straus, M. (1981). Interpersonal violence among married and cohabiting couples. Family Relations, 30, 339-347. 
TABLE 1

Coping Factors

\begin{tabular}{|c|c|c|}
\hline Pactor & Item & $\begin{array}{l}\text { Pactor } \\
\text { coading }\end{array}$ \\
\hline \multirow[t]{2}{*}{$\begin{array}{l}\text { Denial/ } \\
\text { Distancing }\end{array}$} & $\begin{array}{l}\text { don't let it get to me; refuse } \\
\text { to think too much about it }\end{array}$ & .79 \\
\hline & go on as if nothing had happened & .71 \\
\hline \multirow[t]{2}{*}{$\begin{array}{l}\text { Accepting } \\
\text { Responsibility }\end{array}$} & $\begin{array}{l}\text { wish that I could change what had } \\
\text { happened or how I feel }\end{array}$ & .69 \\
\hline & $\begin{array}{l}\text { realize I brought the problem on } \\
\text { myself }\end{array}$ & .69 \\
\hline \multirow[t]{2}{*}{$\begin{array}{l}\text { Problem } \\
\text { Solving }\end{array}$} & $\begin{array}{l}\text { try to see things from my partner's } \\
\text { point of view }\end{array}$ & .68 \\
\hline & $\begin{array}{l}\text { come up with a couple of different } \\
\text { solutions to the problem }\end{array}$ & .63 \\
\hline \multirow[t]{2}{*}{ Confrontation } & blame my partner & .74 \\
\hline & $\begin{array}{l}\text { express anger to my partner about } \\
\text { how I feel }\end{array}$ & .72 \\
\hline \multirow[t]{2}{*}{$\begin{array}{l}\text { Social } \\
\text { Support }\end{array}$} & $\begin{array}{l}\text { ask a relative or friend I respect } \\
\text { for advice }\end{array}$ & .69 \\
\hline & $\begin{array}{l}\text { get sympathy and understanding } \\
\text { from someone else }\end{array}$ & .68 \\
\hline \multirow{2}{*}{$\begin{array}{l}\text { Spiritual } \\
\text { Belief/Pantasy }\end{array}$} & pray & .61 \\
\hline & prepare myself for the worst & .54 \\
\hline $\begin{array}{l}\text { Self } \\
\text { Control }\end{array}$ & $\begin{array}{l}\text { don't do anything I might regret } \\
\text { try not to act too hastily }\end{array}$ & $\begin{array}{l}.65 \\
.60\end{array}$ \\
\hline \multirow{2}{*}{$\begin{array}{l}\text { Escape/ } \\
\text { Avoidance }\end{array}$} & avoid being around other people & .68 \\
\hline & sleep more than usual & .66 \\
\hline
\end{tabular}

Only the first two items on each factor are included in the table. All items and loadings are available from the authors.

$N=257$ 
TABLE 2

Negotiation Pactors

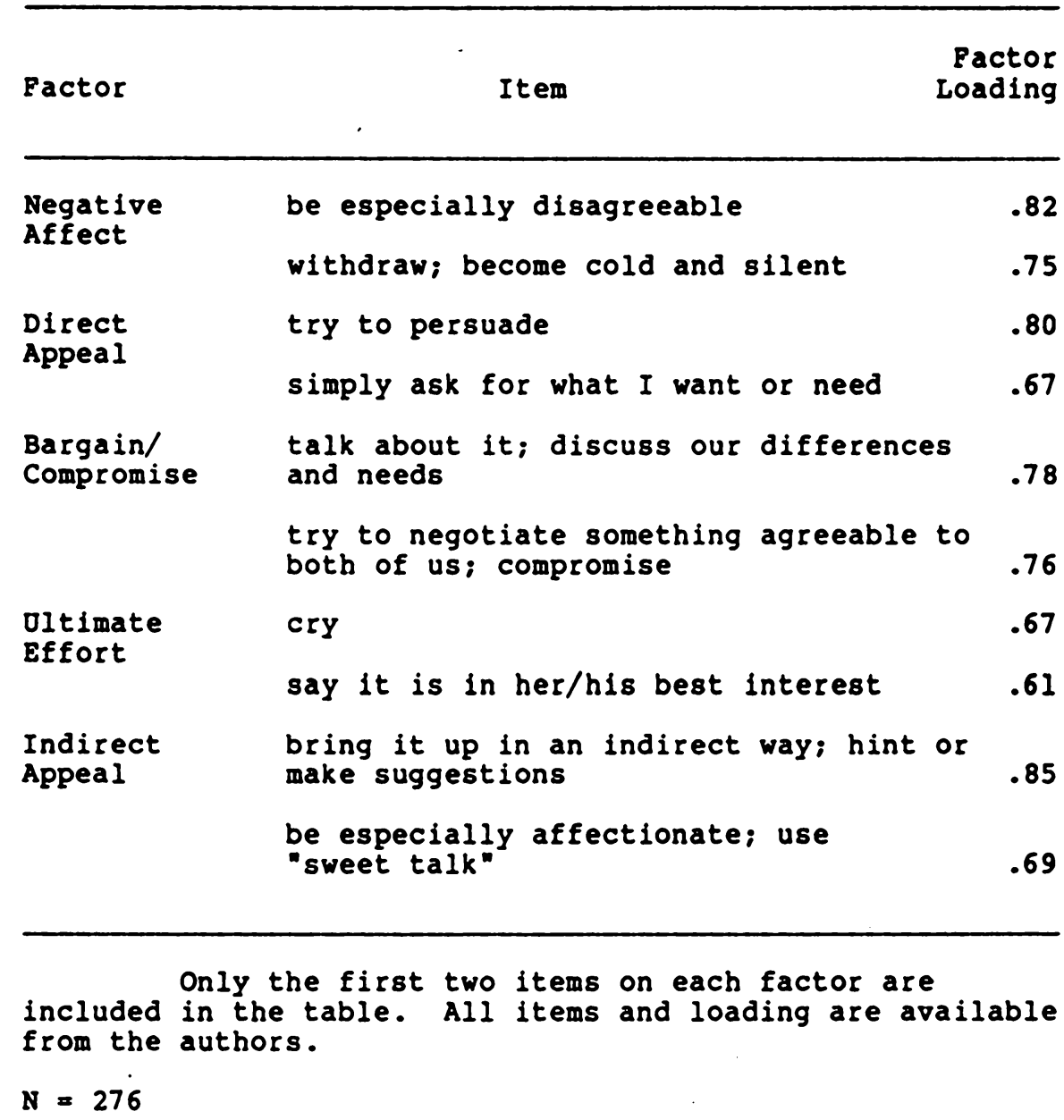


Table 3

Group Means and Standard Deviations

\begin{tabular}{|c|c|c|c|c|}
\hline \multirow[b]{2}{*}{ Variable } & \multicolumn{2}{|c|}{$\frac{\text { Nonviolent }}{N=186}$} & \multicolumn{2}{|c|}{$\frac{\text { violent }}{N=94}$} \\
\hline & Means & $\begin{array}{l}\text { Standard } \\
\text { Deviation }\end{array}$ & Means & $\begin{array}{l}\text { Standard } \\
\text { Deviation }\end{array}$ \\
\hline $\begin{array}{l}\text { Denial/ } \\
\text { Distancing }\end{array}$ & 3.52 & .89 & 3.48 & .98 \\
\hline $\begin{array}{l}\text { Accepting } \\
\text { Responsibility }\end{array}$ & 3.98 & .95 & 3.98 & 1.00 \\
\hline Problem Solving & 4.51 & .95 & 4.53 & .98 \\
\hline Confrontation & 2.98 & 1.12 & 3.51 & 1.12 \\
\hline Social Support & 3.80 & 1.27 & 3.66 & 1.28 \\
\hline $\begin{array}{l}\text { Spiritual Belief/ } \\
\text { Fantasy }\end{array}$ & 3.28 & 1.23 & 3.45 & 1.21 \\
\hline Self Control & 4.58 & 1.47 & 4.28 & 1.42 \\
\hline Escape/Avoidance & 2.95 & 1.04 & 3.31 & 1.19 \\
\hline Negative Affect & 1.89 & .85 & 2.51 & 1.10 \\
\hline Direct Appeal & 4.35 & 1.02 & 4.65 & 1.05 \\
\hline $\begin{array}{l}\text { Bargain/ } \\
\text { Compromise }\end{array}$ & 4.98 & 1.32 & 4.97 & 1.41 \\
\hline Indirect Appeal & 3.35 & .87 & 3.71 & .85 \\
\hline Oltimate Effort & 2.50 & 1.35 & 2.78 & 1.51 \\
\hline Esteem & 5.56 & .89 & 5.44 & 1.06 \\
\hline Mastery & 5.58 & 1.04 & 5.38 & 1.17 \\
\hline
\end{tabular}


Table 4

Stepwise Selection Summary

\begin{tabular}{llll}
\hline$N=274$ & $\begin{array}{l}\text { Partial } \\
\mathrm{R}\end{array}$ & $\begin{array}{l}\text { Wilks } \\
\text { Lambda }\end{array}$ & $\begin{array}{l}\text { Prob } \\
\text { Lambda }\end{array}$ \\
$\begin{array}{l}\text { Variable } \\
\begin{array}{l}\text { Negative Affect } \\
\text { (Negotiation Style) }\end{array}\end{array}$ & .0900 & .910 & .0001 \\
$\begin{array}{l}\text { Confrontation } \\
\text { (Coping Strategy) }\end{array}$ & .0095 & .901 & .0001 \\
$\begin{array}{l}\text { Social Support } \\
\text { (Coping Strategy) }\end{array}$ & .0121 & .890 & .0001 \\
\hline
\end{tabular}


Table 5

Classification summary

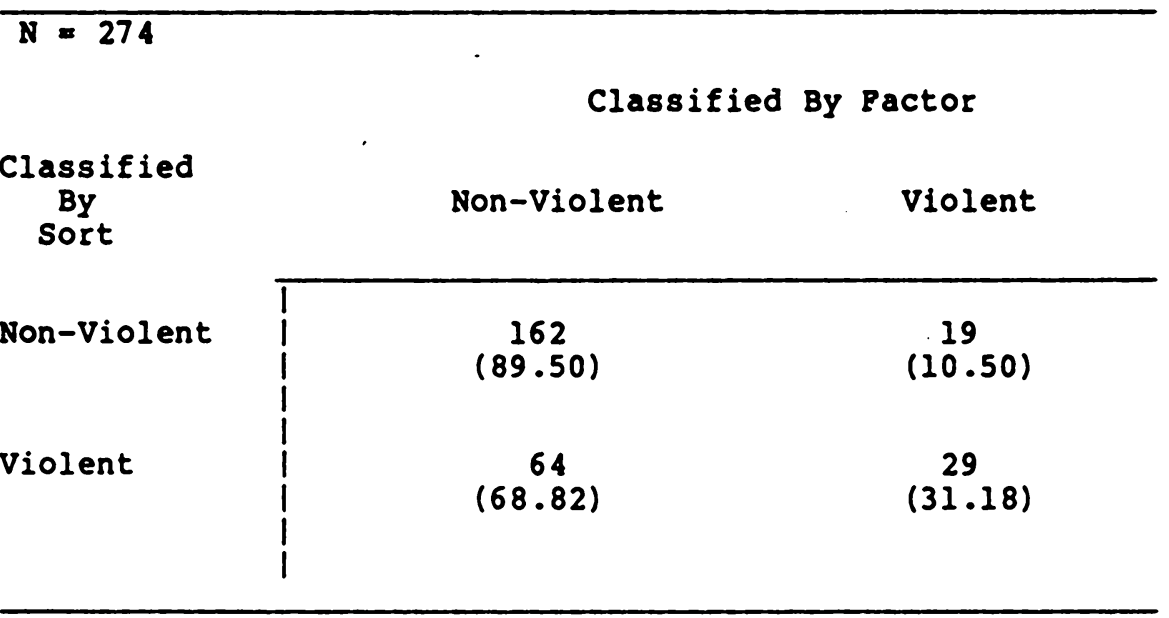

898 of those who identified themselves as having no abusive relationships were correctly classified by the factors as being nonviolent.

318 of those who identified themselves as experiencing abusive relationships were correctly classified by the factors as being violent. 


\section{Literature Review}

Research concerning courtship violence has only been available since Makepeace's study conducted in 1981 . Since then approximately twenty-two studies have examined varying aspects of this phenomenon. This literature review provides an overview of the major studies that have been conducted regarding the incidence of courtship violence. It focuses on those studies directly related to this investigation.

Initial explorations of courtship violence were atheoretical and predominantly directed towards determining incidence, description, prediction, and definition of the problem. All of the reviewed studies used some version of the Conflict Tactics Scale (Straus, 1979) to measure the type of violence and relied on survey methodology to collect data from samples of university students.

Makepeace (1981), surveyed 202 college students and discovered that 218 of participants acknowledged having at least one personal experience involving violence with a dating partner. In addition, 628 of participants knew of others who had been involved in abusive dating relationships. Makepeace not only estimated the incidence of dating violence, but described the types of violence in which respondents participated and identified "basic social correlates of the phenomenon" (p. 97). The results indicated that pushing, shoving, and slapping were 
predominant types of abuse followed by threatening, punching and striking with an object. Severely violent acts including choking and assault with a weapon were acknowledged by less than 28 of respondents.

Sources of disagreement precipitating violence included jealousy, sexual pressure, and drinking behavior. Women overwhelmingly perceived themselves as victims (928), while only 708 of male participants considered themselves as aggressors. About half of those who had experienced violence with a dating partner terminated the relationship as a result of the abuse.

In 1983, Makepeace initiated another study exploring the relationship between life change stress and courtship violence. This project utilized responses from 244 college students and measured life events stress. Results indicated that only undesirable life event changes for male respondents, such as school and peer relationship problems, were related to courtship violence. Events associated with family violence (financial pressure and family stress) were not reported to be associated with dating violence. These findings indicate that the life events related to courtship violence are unique to the life cycle stage of the dating partners.

His most recent project (Makepeace, 1987) examined social factor differences between four types of respondents; those participants who have experienced dating 
violence, those who have not experienced dating violence, male offenders, and female victims. The social factors studied include background factors (demographics); experiential factors such as parenting styles, dating history, substance abuse, and school achievement; and character variables, to include social isolation, self-esteem, and social stress. Makepeace concluded that experiences differ between those participants reporting courtship violence and those who had never been involved in an abusive dating relationship. Results from this survey indicated no relationship between self-esteem and involvement in violent dating relationships.

Cate, Henton, Koval, Christopher, and Lloyd (1982) proceeded Makepeace's (1981) original descriptive study with a social psychological investigation of dating violence concerning interpretation of the abuse by participants, reciprocity, and attitudes toward abuse. This project utilized questionnaire responses from 355 college students. The abuse incidence rate of 228 closely paralleled Makepeace's findings. Anger, confusion, and love were described most frequently by respondents as explanations for the violence. Reciprocity was indicated in $68 \%$ of abusive relationships. Only 228 reported that violence caused the relationship to deteriorate and more than half of the respondents remained in relationships after violence had occurred. 
In 1983, these same researchers (Benton, Cate, Koval, Lloyd, \& Christopher) conducted the first of only two studies investigating dating violence at the high school level. They surveyed 644 students from five schools and determined that 128 of the participants had personally experienced violence in a dating relationship. Of that 128,418 were still dating the partner with whom the violence had occurred. Henton et al. discussed the acceptance of relationship violence by dating couples and concluded that male participants in abusive relationships reported significantly more positive attitudes towards violence than either those who had never experienced courtship abuse or those females who had been involved in premarital violence.

Laner and Thompson (1982) tested hypotheses about courtship violence encompassing components of conflict and choice and exchange theory. They concluded that abuse is more likely to occur during stages of serious involvement rather than in casual dating relationships. Laner (1983) went on to publish other results from this study addressing contextual aspects of dating violence. Male participants viewed the violence as being mutual (688) more often than did females (488). Both men and women perceived the cause of the violent interactions to be either personal or interpersonal in nature rather than situational. The majority of violent incidences were not drug or alcohol 
related and usually occurred in private settings with no witnesses.

Only one investigation has examined characteristics of ongoing relationships (Roval \& Lloyd, 1986). In a survey of 644 college students they utilized a scale developed by Falbo and Peplau (1980) to determine if choice of power strategies differentiated between violent and nonviolent dating partners. Results showed that respondents currently involved in violent partnerships used more indirect power strategies, such as pouting and withdrawal, whereas those who had not experienced courtship abuse utilized direct unilateral power strategies that include asking and statement of needs.

In 1986, Deal and Wampler proposed a multi-causal model of dating violence including past experiences, attitudes, personality and situational factors, and socioeconomic status. In this study of 410 undergraduate students they assessed self-esteem using Rosenberg's Self-Esteem Scale (1965) and concluded that self-esteem is a significant predictor of involvement in courtship violence.

It is obvious by the research that a substantial number of young people maintain dating relationships in which violence occurs. While previous studies have established important information about courtship violence, it is imperative that factors which may relate to the 
decision to remain in an abusive relationship be investigated in order to clarify the relationship between these variables. 
APPENDIX B

METHODOLOGY

$-42-$ 
Methodology

This appendix elaborates on the procedures used for the pilot study and data collection utilized in this study.

\section{Pilot Study}

In April, 1987, a pilot survey was administered to a sample of fifteen university students. The purpose of the pilot was threefold: to identify any ambiguous or confusing terminology, to determine if response choices provided adequate item variance, and to obtain overall reactions to the questionnaire. In some cases, item terminology was altered as a result of feedback from pilot participants.

Data Collection

Data was collected from a random sample of three hundred female and three hundred male college freshman living in campus dormitories at Virginia Tech $(\mathrm{N}=600)$. This selection procedure was chosen in order to limit the study to adolescent dating relationships, diminish the number cohabitating couples and reduce age variation in the sample.

The research design was based on Dillman's (1978)

Total Design Method for mail questionnaires. The questionnaire consisted of a screening question, three $8^{n} \mathbf{x}$ 
$12^{n}$ sheets of paper, and a cover sheet folded and stapled in the middle to form a booklet, the dimensions of which are $6^{n}$ by $8^{n}$ (Appendix C). The cover, graphically designed to create a positive impression, included the title, Dating Relationship Research Project, and affiliation, Department of Family and Child Development, Virginia Polytechnic Institute and State University, to establish the legitimacy of the study. The instrument was produced on computer and printed on white paper. The cover was gray with blue lettering. Special consideration was given to the entire format of the questionnaire in order to create a professional image and denote to respondents the importance of the study.

A survey packet consisting of the twelve page booklet, a cover letter describing the project, a screening question defining eligibility for participation, and a stamped, pre-addressed return envelope was sent to each participant. In keeping the Dillman's (1978) approach a post card (Appendix D) was sent one week after the initial mailing requesting completion of the survey by those who had not done so and thanking participants who had already responded. Fifteen days after the original mailing a follow-up letter was mailed to nonrespondents (Appendix D). A final mailing, consisting of a letter, replacement questionnaire, and a stamped, pre-addressed envelope was sent to all remaining non-respondents. 
Responses were received from 401 individuals resulting in a response rate of 678 . This figure was calculated as the percentage of students in the sample from whom responses were received (Dillman, 1978).

Questionnaires were all coded twice in order to insure greater accuracy in the location of coding errors. Negatively worded items were reverse coded to read in a positive direction. All analyses were computed through use of the Statistical Analysis System (SAS) (Helwig \& Council, $1986)$.

Responses to the 41 coping items were factor analyzed to reduce and organize the data. The type of factor analysis used was principal factoring with iteration. This method of analysis extracts the number of factors with eigenvalues greater than or equal to 1.0. The varimax technique was used to rotate the axis orthogonally. The resulting eight factors are described as dimensions of coping.

The same procedure was calculated for items identifying negotiation styles. These 21 items were reduced to five factors describing techniques used in negotiation (see Appendix E). 
Cate, R.M., Henton, J.M., Roval, J., Christopher, F.S., \& Lloyd, S. (1982). Premarital abuse: A social psychological perspective. Journal of Family Issues, 3, 79-90.

Deal, J., \& Smith Wampler, R. (1986). Dating violence: The primacy of previous experience. Journal of Social and Personal Relationships, $3,457-471$.

Dillman, D.A. (1978). Mail and telephone surveys: The totól design method. New York: Wiley-Interscience.

Falbo, T., \& Peplau, L.A. (1980). Power strategies in intimate relationships. Journal of Personality and soccial Psychology, 38, 618-628.

Helwig, J.T., \& Council, R.A. (Eds.). (1984). SAS_user's guide. Raleigh, NC: SAS Institute.

Henton, J., Cate, R.M., Roval, J., Lloyd, S.A., \& Christopher, F.S. (1983). Romance and violence in dating relationships. Journal of Family Issuess, 4, 467-482.

Roval, J.E., \& Lloyd, S.A. (1986). Premarital violence:

Examining relationship factors as possible contributors. Paper presented at the National Council on Family Relations Annual Conference, Dearborn, Michigan, November 2-7, 1986 .

Laner, M.R., \& Thompson, J. (1982). Abuse and aggression in courting couples. Deviant_Behavior: An

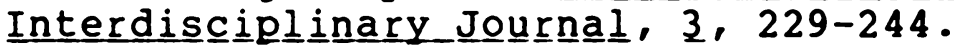

Laner, M.R. (1983). Courtship abuse and aggression: Contextual aspects. Sociological spectrum, 3 , 69-83.

Makepeace, J.M. (1981). Courtship violence among college students. Family Relatiㅡ믄, 30, 97-102.

Makepeace, J.M. (1983). Life events stress and courtship violence. Family Relations, 32, 101-109.

Makepeace, J.M. (1987). Social factor and victim-offender differences in courtship violence. Family Relatiㅡ믄, 36 , 87-91. 
Rosenberg, M. (1965). Society and the adololescent sele image. Princeton, NJ: Princeton University.

Straus, M. (1979). Measuring intrafamily conflict and violence: The conflict tactics scales. Journal of Marriage and the Family, 41, 75-88. 
APPENDIX C

INSTRUMENT

- $48-$ 


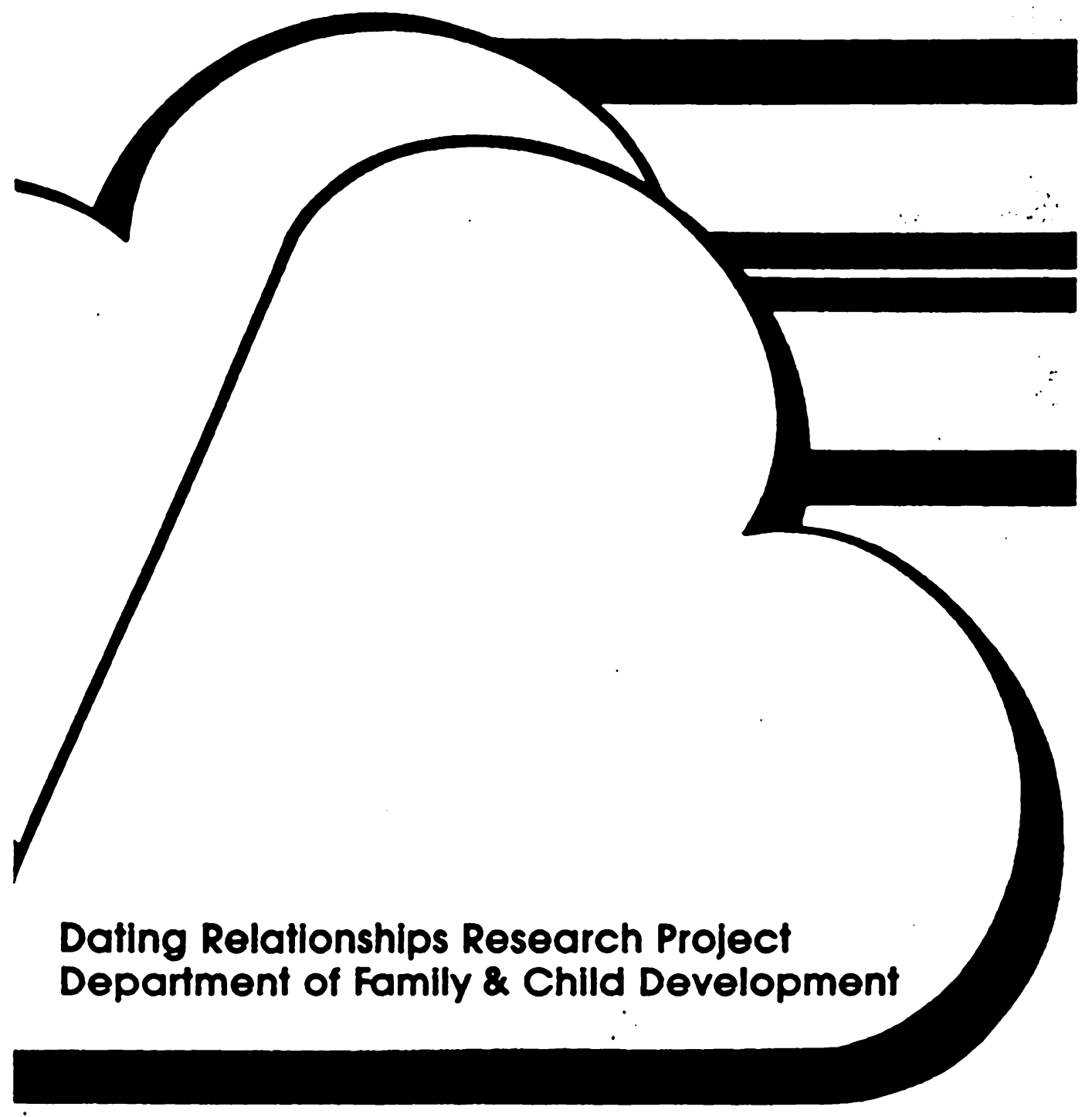

Virginia Polytechnic Institute antd State University 
This questionnaire is designed to obtain information from people who have been involved in a dating relationship within the last two years. You have received this questionnaire because your name was randomly selected from the freshman class at Virginia Tech so that a realistic portrayal of dating relationships among university women and men is possible.

However, we want to be sure that you should fill out the questionnaire. Please circle the number in front of the statement that best describes your current dating status.

1. Casually dating; have not had a serious dating partner within the past two years.

2. Casually dating; have had a serious dating partner within the past two years.

3. Seriously dating one person.

4. Engaged.

IF YOU CIRC:LED NUMBER 2, 3, OR 4, PIIIASSI: FILL OUT THE OUESTIONNAIRE ANI) RI:TURN II IN (III: SI:(I-AI)I)RI:SSIII), STAMPED ENVELOPE.

IF YOU CIRCLIED NUMBI:R 1, PIIIAST: RETURN TIII QUIESTIONNAIRI: (WITHOUT ANSWERING $\Lambda$ NY OF: TIII: QUI:STIONS) TO US IN THII SELF-ADDRESSEI), STAMPIID I:NVI:I.OPI:. 


\section{Part A}

Firsh it is important that we gain a greater understanding of the nawre of your dating relationship. G.en how you feel about the relationship. what you discuss with each other). Gircle numbers to the right and left of each of the items 10 indicate how oten both you and your dating parner do the following things.

How Ofien Do You How Often Does Yow Parner

\begin{tabular}{|c|c|c|c|c|c|c|c|c|c|c|}
\hline \multicolumn{2}{|c|}{ Never } & \multicolumn{3}{|c|}{$\begin{array}{l}\text { Very } \\
\text { oflen }\end{array}$} & \multicolumn{4}{|c|}{ Never } & \multicolumn{2}{|c|}{$\begin{array}{l}\text { Ve } \\
\text { of }\end{array}$} \\
\hline 1 & 2 & 3 & 4 & 5 & $\begin{array}{l}\text { Tall about the quality of the } \\
\text { relationship (hov' good it is, hou } \\
\text { satisfying. how to improve it) }\end{array}$ & 1 & 2 & 3 & 4 & \\
\hline 1 & 2 & 3 & 4 & 5 & $\begin{array}{l}\text { Discuss how much each person } \\
\text { gives to the redationship }\end{array}$ & 1 & 2 & 3 & 4 & \\
\hline 1 & 2 & 3 & 4 & 5 & $\begin{array}{l}\text { Tell the other what is wanted. or } \\
\text { needed from the relationship }\end{array}$ & 1 & 2 & 3 & 4 & \\
\hline 1 & 2 & 3 & 4 & 5 & $\begin{array}{l}\text { Talk about hor close you feed to } \\
\text { the other }\end{array}$ & 1 & 2 & 3 & 4 & \\
\hline 1 & 2 & 3 & 4 & $s$ & $\begin{array}{l}\text { Tell the other hou special this } \\
\text { relationship is, compared with } \\
\text { others }\end{array}$ & 1 & 2 & 3 & 4 & \\
\hline 1 & 2 & 3 & 4 & 5 & $\begin{array}{l}\text { Talk about feeling that what } \\
\text { happens to onc also affects } \\
\text { the other }\end{array}$ & 1 & 2 & 3 & 4 & \\
\hline 1 & 2 & 3 & 4 & 5 & $\begin{array}{l}\text { Say that there is a sense of } \\
\text { "belonging" with each other }\end{array}$ & 1 & 2 & 3 & 4 & \\
\hline 1 & 2 & 3 & 4 & 5 & $\begin{array}{l}\text { Express feetings of commitment } \\
\text { to the relationship }\end{array}$ & 1 & 2 & 3 & 4 & \\
\hline 1 & 2 & 3 & 4 & $s$ & $\begin{array}{l}\text { Spend time discussing and trying } \\
\text { to work out problens }\end{array}$ & 1 & 2 & 3 & 4 & 5 \\
\hline 1 & 2 & 3 & 4 & 5 & Say bow much the otber is needed & 1 & 2 & 3 & 4 & 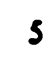 \\
\hline I & 2 & 3 & 4 & 5 & $\begin{array}{l}\text { Disclose very intimate things to } \\
\text { the other }\end{array}$ & 1 & 2 & 3 & 4 & J \\
\hline 1 & 2 & 3 & 4 & 5 & $\begin{array}{l}\text { Tell the other how much in love } \\
\text { you are }\end{array}$ & 1 & 2 & 3 & 4 & 5 \\
\hline 1 & 2 & 3 & 4 & 5 & $\begin{array}{l}\text { Try to change behivior to help } \\
\text { solve probiems betweed you }\end{array}$ & 1 & 2 & 3 & 4 & \\
\hline
\end{tabular}


In your relationship with your dating partner.

How Oftes Do You:

Niever oflen

1. Gea confused about hor you feel

$\begin{array}{lllll}1 & 2 & 3 & 4 & 5\end{array}$

2. Think or worry about losing some of your independence

3. Feel unsure about continuing the relationship

$\begin{array}{lllll}1 & 2 & 3 & 4 & 5\end{array}$

4. Feel that your dating partiner demands or requires too much time and atrention

5. Argue with each other

$\begin{array}{lllll}1 & 2 & 3 & 4 & 5\end{array}$

6. Try to change things about your partner that botber you

$\begin{array}{lllll}1 & 2 & 3 & 4 & 5\end{array}$

12345

$\begin{array}{lllll}1 & 2 & 3 & 4 & 5\end{array}$

7. Feel "trapped" or pressured to continue the relationship

$\begin{array}{lllll}1 & 2 & 3 & 4 & 5\end{array}$

8. Feel angry or resentul toward your dating parrzer

9. Communicate neqative feelings (anger. dissatisfacion, frustration) toward your parnet $\quad 1 \quad 2 \quad 345$

10. Have serious disagreements about problems that threaten to lead to a breakup

11. How long have you been in this dating relationship?

(months/years)

\section{Part B}

In close relationships most people experience instances where both partners feel very strongly aboul a siwation. Each feels compelled to infuence the other 10 do what be/she wants. When you want to influence your parser to do things your way, to what extent do you use the following strategies? (Gircle number)

1. Simply ask for what I want or need

Never Sometimes Always

2. Try to persuade

$\begin{array}{lllllll}1 & 2 & 3 & 4 & 5 & 6 & 7\end{array}$

3. Repeatedly make my point until

.. he/sbe gives in

125345567

4. Use logic and reasoni give all the reasons my way is bert

$123 \ldots 4567$

$\begin{array}{lllllll}1 & 2 & 3 & 4 & 5 & 6 & 7\end{array}$ 
5. Bring it up in an indirect way; hint or make suggestions

6. Say bow very important my request is; how much it means 10 me

7. Say it is in her/his best interest

8. Talk about iti discuss our differences and neods

9. Use my expertise: claim I have a lor of experience in such matuers:

10. Be especially affectionale; use "sweet Lalk"

11. Appeal to a sense of faimess; say its the only fair and right thing to do

12. Tru in negotiate something agrecable to both of us: compromise

13. Do some "fast talking"

14. Lie

15. Withdran: become cold and silent

16. Be especially disagreeable

17. Discuss the issue heatedly

18. Insult or swear at

19. Leave the room, house, etc.

20. $\mathrm{Cr}$

21. Threaten to break up

\section{Never Sometimes Always}

$\begin{array}{lllllll}1 & 2 & 3 & 4 & 5 & 6 & 7\end{array}$

$\begin{array}{lllllll}1 & 2 & 3 & 4 & 5 & 6 & 7\end{array}$

$\begin{array}{lllllll}1 & 2 & 3 & 4 & 5 & 6 & 7\end{array}$

1234567

$\begin{array}{lllllll}1 & 2 & 3 & 4 & 5 & 6 & 7\end{array}$

$123 \quad 3 \quad 4 \quad 5 \quad 6 \quad 7$

$\begin{array}{lllllll}1 & 2 & 3 & 4 & 5 & 6 & 7\end{array}$

12534567

$123456=$

1234567

$123 \quad 3 \quad 4 \quad 5 \quad 6 \quad 7$

$123 \quad 4 \quad 5657$

$122 \quad 3 \quad 45567$

$\begin{array}{lllllll}1 & 2 & 3 & 4 & 5 & 6 & 7\end{array}$

$\begin{array}{lllllll}1 & 2 & 3 & 4 & 5 & 6 & 7\end{array}$

12534.5679

$\begin{array}{lllllll}1 & 2 & 3 & 4 & 5 & 6 & 7\end{array}$

22. In general, to what extent do you think you can influence your parner's behavior?

$\begin{array}{ccccc}\text { Niever } & \text { Rarely } & \text { Sometimes } & \text { Ofien } & \text { Alyays } \\ 1 & 2 & 3 & 4 & 5\end{array}$

23. Who usually wins major disagreements in your relationship?

$\begin{array}{ccccc}\text { Partner } & \text { Parner } & \text { About } & \text { Me } & \text { Me } \\ \text { Awways } & \text { Usually } & \text { Equal } & \text { Usually } & \text { Nways } \\ 1 & 2 & 3 & 4 & 5\end{array}$




\section{Part C}

After an argument with your dating partner, when nothing is really settled and you feel very upset, to what extent do you: (Curcle number)

\section{Never Sometimes Always}

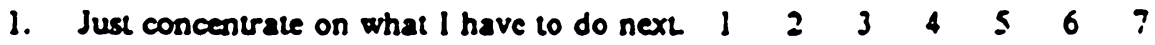

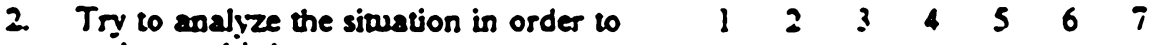
understand it beter.

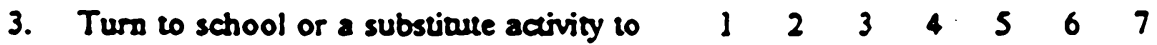
take my mind of things.

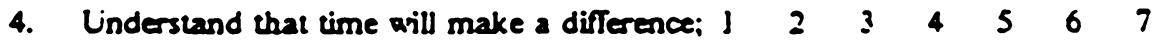
the only thing to do is wail

5. Try to get my partier to change.

6. Blame mysels.

i. Don't do anvehing I might regrel

8. Hope a miracle will happen to solve everything.

9. Go on as if nothing had happened.

10. Try to keep my feelings to myself.

11. Sleep more than usual.

12. Express anger to my parner about hor $\quad \begin{array}{lllllll}3 & 2 & 3 & 4 & 5 & 6 & i\end{array}$ 1 sed.

13. Get sympathy and understanding from $1 \begin{array}{llllllll} & 2 & 3 & 4 & 5 & 6 & 7\end{array}$ someone else.

14. Tell myself things that help me to feel betier. $1 \quad 2 \quad 344567$

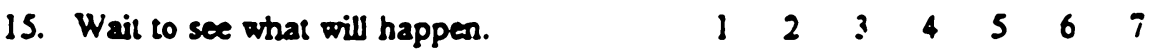

16. Apologize or do something to make up. $\begin{array}{lllllll}1 & 2 & 3 & 4 & 5 & 6 & 7\end{array}$

17. Make a plan of action and follow in $\quad 1 \quad 2 \quad 344567$

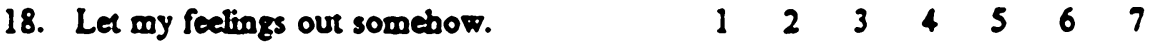

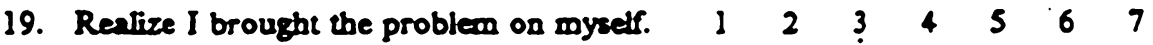

20. Try to make myself foel better by eating, $1 \quad 2 \quad 344567$ drinking, smoking, using drugs, etc.

21. Try not to act too hastily. $\quad 1 \quad 20 \begin{array}{lllllll} & 4 & 5 & 6 & 7\end{array}$

22. Change something so things will turn out $1 \quad 2 \quad 344567$ all right 


\section{Niever Sometimes Always}

23. Avoid being around other poople.

$123.1^{4} 56 \quad 6$

24. Don't let it get to me; refuse to thint $100 \quad 1 \quad 2 \quad 34456$ i much abour it

25. Ask a relative or friend I respect for advice. $1 \quad 2 \quad 3 \quad 4 \quad 5.67$

26. Keep others from knowing how bad things $1 \quad 2 \quad 3 \quad 4 \quad 5 \quad 6 \quad 7$ are.

27. Make ligh of the siwation: refuse to get $\quad \begin{array}{lllllll}2 & 3 & 4 & 5 & 6 & 7\end{array}$ 100 serious about it.

28. Blame my partoer. $152 \quad 344567$

29. Make a promise to myself that things will $1 \quad 2 \quad 344567$ be different pext lime.

30. Come up with a couple of different solutions I 2 3 4 5 6 ? io the problem.

31. Accept iL since nothing can be donc. 1 2 345

32. Wisb that I could change what had $11 \quad 2 \quad 3 \quad 4 \quad 5 \quad 6 \quad 7$ happesed or hor I feel.

33. Vow to change something about mysels. $1 \quad 2 \quad 3 \quad 4 \quad 5 \quad 6 \quad 7$

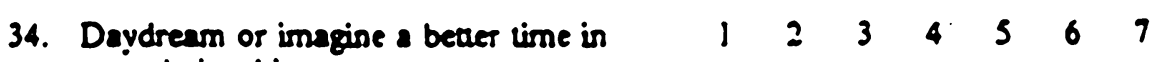
our relationship.

35. Wish that the siwation would go away or 12934567 somebow be over with.

36. Pray.

37. Prepare myself for the worsh

38. Go over in my mind what 1 will say or do. $1 \quad 2 \quad 3 \quad 4 \quad 5 \cdot 6 \quad 7$

39. Try to see things from my parter's point $1 \quad 2 \quad 3 \quad 4 \quad 5 \quad 67$ of view.

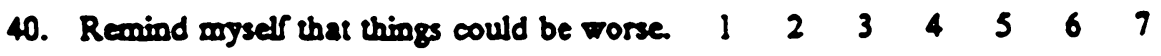

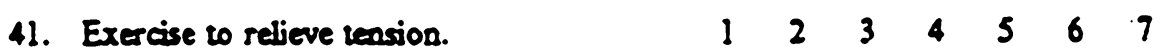




\section{Part $\cdot \mathrm{D}$}

When other means of communication don't work. physical arguments may resull The following list describes things that dating partners have sometimes done during such an argument. Please indicale whether you or your parner have done any of the following. (See example belot:)

$\begin{array}{ccccc}\text { Threatened } & \text { Never } & \text { Rarely } & \text { Occasionally } & \text { Frequenuy } \\ \text { Only } & \text { Done } & \text { Done } & \text { Done } & \text { Done } \\ 1 & 2 & 3 & 4 & 5\end{array}$

You

Your Partiner

\begin{tabular}{|c|c|c|c|c|c|c|c|c|c|c|}
\hline 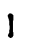 & 2 & 3 & 4 & 5 & pushed. shoved. grabbed & 1 & & & 3 & 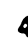 \\
\hline & 2 & 3 & 4 & 5 & wrestled or pinned doan & & & & 3 & A \\
\hline & 2 & 3 & 4 & 5 & threx an object at & & & & 3 & \\
\hline & $\Xi$ & 3 & 4 & $s$ & clawed. scralched. bil & & & & 3 & \\
\hline & , & 3 & 4 & 5 & slapped & & & & 3 & \\
\hline & 2 & 3 & 4 & 5 & punched with fist & & & & 3 & 6 \\
\hline & 2 & 3 & 4 & 5 & hit with object & 8 & & & 3 & 4 \\
\hline & 2 & 3 & 4 & 5 & kicked & 1 & & & 3 & 4 \\
\hline & 2 & 3 & 4 & 5 & atcempled to stranglc & 1 & & & 3 & 4 \\
\hline & 2 & 3 & 4 & $s$ & $\begin{array}{l}\text { used lechal weapon } \\
\text { (knife, gun, etc.) }\end{array}$ & 1 & & & 3 & 4 \\
\hline
\end{tabular}

- If You Answered With a 1 Or $\underline{2}$ To All Items Above, Go To Item Part F

13. Hox is the physical argument maintained?

1. Parner initiates; I toy to get away

2. Parner initiates; 1 oy to protect myself

3. Partner initiates; I Gght back

4. I initiale; Partier tries to get away

5. I initiate, Partrer tries to protect self

6. I initiate, Partner fights back

14. What is the most common source of physical arguments in your relationship? (Gircle number)

1. Jealousy over involvement or perceived involvement, with another person

2. Use of alcohol or drugs

3. Sexual pressure

4. Other (please specify) 
15. Does this Illustration represent the pattern of bow physical arguments occur in your dating relationship?

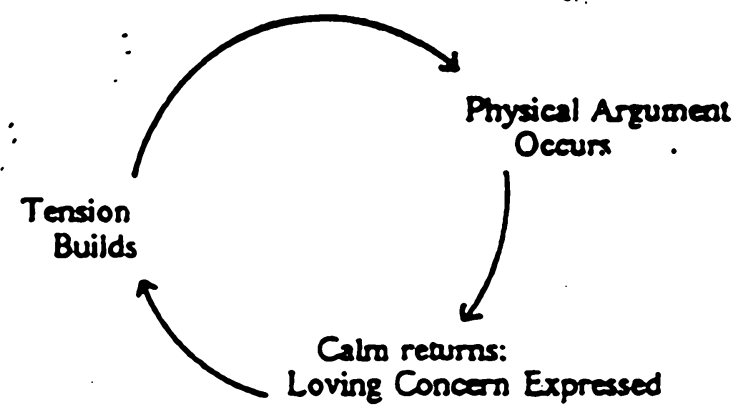

(Circle answer)

1. Yes

2. Nol sure

3. No If No, please describe the patuera as it occurs in your relacionship.

16. In what stage of the relationship did physical aguing begin?

1. Casual dating

2 Serious datiog

3. Engaged

4. Orber (please specify)

1i. What was the eftect of the physical arguing on your relationship?

1. Relationship got worse

2. Relationship stayed the same

3. Relationship improved

18. How old were you when you first experienced a physical argument with a dating parner?

(age)

19. Have you experienced physical argumeots with any other datiog partoer? (Circle number).

1. No

2. Yes If Yes, in bow many relationships have you experiencod physical arguments?

(Number) 


\section{Part E}

Atter a disagreement with your partịer, when an argument has been physical. to what extent do you feel:
Not.
Aitule
Ai All
Somewhat
Lot Exsemely

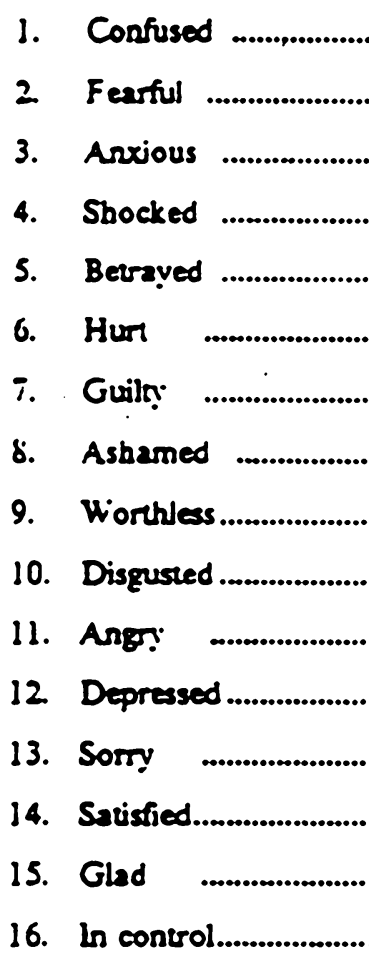

\section{2}

2

2

2

2

2

2

2

2

2

2

2

2

23

23

23

2

3

$\begin{array}{ll}4 & 5 \\ 4 & 5 \\ 4 & 5 \\ 4 & 5 \\ 4 & 5 \\ 4 & 5 \\ 4 & 5 \\ 4 & 5 \\ 4 & 5 \\ 4 & 5 \\ 4 & 5 \\ 4 & 5 \\ 4 & 5 \\ 4 & 5 \\ 4 & 5 \\ 4 & 5\end{array}$

\section{** Part F}

Because dating relationships set the stage for marriage we would like to know bow you fed abour the following frovily soles: husbend, wife, mother, and fatber. (Cirde number)

Stroogidy

Disagee

Strongty Afree

1. A wife sbould have equal authority with $1 \quad 2 \quad 3 \quad 4 \quad 5 \quad 6 \quad 7$ ber busband in making fomily decisions.

2. A married woman's mox important lask $1 \quad 2 \quad 3 \quad 4 \quad 5 \quad 6 \quad 7$ in Iffe should be caring for ber family.

3. A married woman's greatest reward and $1 \quad 2 \quad 3 \quad 4 \quad 5 \quad 6 \quad i$ intiffaction bome through childrea. 
4. A mother of young children should work only if the family needs money.

5. A woman's carees should be just as important to her as encouraging ber busband in his career.

6. A wife should make long tange career plans just as ber husband does.

7. A woman who works, should use the same strategies for career advancement that a man does.

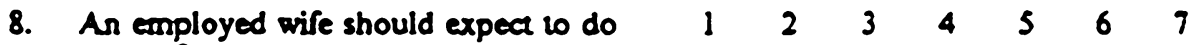
most of the household chores herself.

9. A aife should give up her joh if it interferes with being a wife and mocher.

10. A mother should not be upset if her children feel as close or closer to their father as to ber.

11. A woman should find her career as salisfying as being a wise and mother.

12. A wife should not be disturbed if she roakes more money than her busband.

13. An employed mother can establish just as $1 \quad 2 \quad 3 \quad 4 \quad 5 \quad 6 \quad 7$ warm and secure a relationship with ber children as a non employed mother.

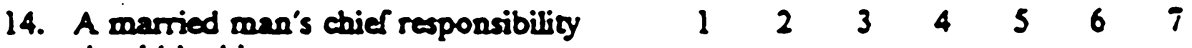
should be his career.

15. A married man's most important task in 1 l $2 \quad 3 \quad 4 \quad 5 \quad 6 \quad 7$ life should be providing financial support for his family.

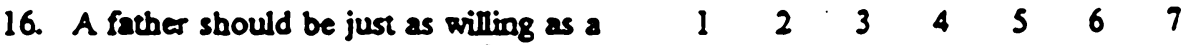
mother 20 miss work to care for a sick child.

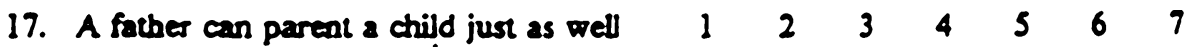
as a mother.

18. A husband should not be upset if his wife's career somecimes requires ber to be away from bome overnight.

19. A married man's greatest reward and satisfaction should come from his career. 


\section{Stroagly \\ Disagree}

20. A husband should nol be diswrbed if his 1 2 344567 wife makes more money than he does.

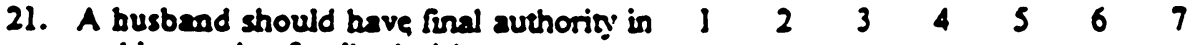
making major family decisions.

22. A husband should ourn down a promotion $1 \quad 2 \quad 3 \quad 4 \quad 5 \quad 6 \quad 7$ if it means spending less time with his fernily.

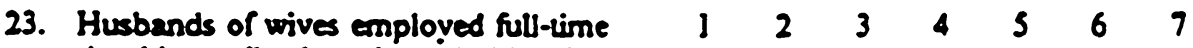
should equally share bouschold lasks (i.e., doing the laundry, vacuuming. prepariog meals).

24. Ir both spouses are comploved full-time. $\quad \begin{array}{llllllll}2 & 3 & 3 & 4 & 5 & 6 & i\end{array}$ the husband should equaliy share child care lasks (i.e., changing diapers. bathing children. Laking children 20 and from day care).

25. A busband should be willing to move is his 1 ? $34 \leq 6$ ? wife is offered a beter job in another wown.

\section{Part G}

Nox. it's important that we know more about how you vien yourselr. Please give an honest appraisal of your feelings by reacing to the next fea items.

Strongly
Disagee

1. On the whole. I'm satisfied with myselr. $1 \quad 2 \quad 3 \quad 4 \quad 5 \quad 6 \quad i$

2. I am able 10 do things as well as most $1 \quad 2 \quad 3 \quad 4 \quad 5 \quad 6 \quad 7$ otber people

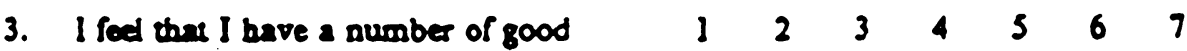
quatities.

4. I lake a positive atioude woward mysels. I $2 \begin{array}{llllll} & 3 & 4 & 5 & 6 & 7\end{array}$

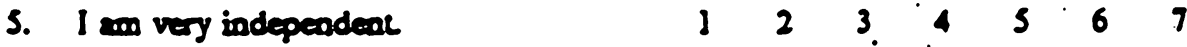

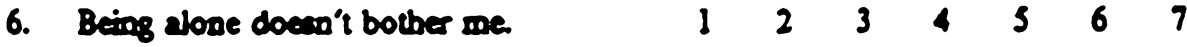

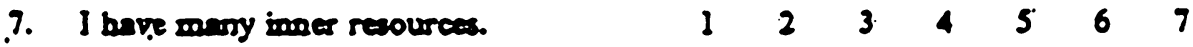

8. I eajoy doing things by myself. $\quad 1 \quad 2 \quad 3 \quad 4 \quad 5 \quad 6 \quad 7$

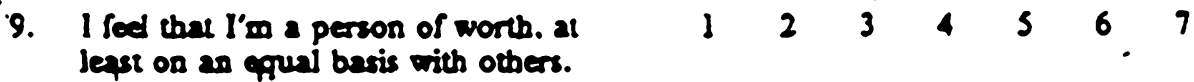

10. At tiones I think I'm no good at all. 1 ? 3445667 


\section{Strongly Strongly \\ Disagree Agree}

11. I feel I don't have much to be proud of. $1 \quad 2 \quad 3 \quad 4 \quad 5 \quad 6 \quad 7$

12. There is litle I can do to change many $1 \quad 2 \quad 3 \quad 4 \quad 5 \quad 6 \quad 7$ of the important things in my life.

13. Sometimes I feet that I'm being pushed $1 \quad 2 \quad 3 \quad 4 \quad 5 \quad 6 \quad 7$ around in life.

14. All in all. I'm inclined to foel that $\quad 1 \quad 2 \quad 3 \quad 4 \quad 5 \quad 6 \quad 7$ I'm a failure.

15. There is really no way 1 can solve some $1 \quad 2 \quad 3 \quad 4 \quad 5 \quad 6 \quad 7$ of the problems I have.

16. I have livle control over the things that $1 \quad 2 \quad 3 \quad 4 \quad 5 \quad 6 \quad 7$ happen to me.

17. 1 ofien feel helpless in dealing with the $\begin{array}{lllllll}1 & 2 & 3 & 4 & 5 & 6 & 7\end{array}$ problems of life.

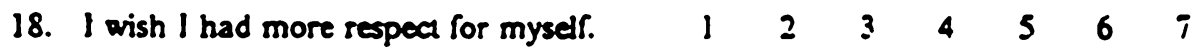

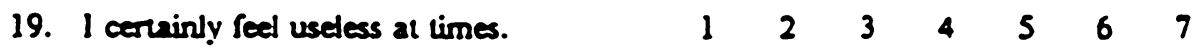

\section{Part H}

Finally, we would like to request some general information needed to help interpret the results of the soudy.

1. How old are you?

$$
\text { (vears) }
$$

2. Which one of the following best describes your racial of ethric identification?
1. Black
2. White (Caucasian)
3. Other (specify)

3. What is your sex? (Circle number)
1. Female
2. Male

4. To what extent do your parents support you financially?

1. 100\% Supporied By My Parents

2. They Mostly Support Me, But I Have Some lncome Or My Own

3. About 50\% Supported By My Parents

4. I Am Mostly Independent, But I Receive Some Support

5. 100\% Finacially lodependent

5. How many brothers and sisters do you have?

$\overline{\text { (Brothers) }} \overline{\text { (Sisters) }}$ 
6. What is the employment status of your parents? (Gircle number for each)

\section{Mother}

1. Employed Full-Time (more than 35 hrs/wh)

2. Emploved Par-Time less than 35 hrs/wok)

3. Not Employed Outside The Home

4. Retired

5. Other
Father

1. Emploved Full-Time (more than 35 hrs/ok)

2. Employed Part-Time (less than 35 hrs/owk)

3. Not Employed Outside The Home

4. Retired

5. Other

7. Where are your parents employed? (Leave blank if not employed)

Mother

Father

8. What are your parents occupations? (Leave blant of not employed)

Mother

Father

9. What is the marital staus of your parents (Circle number for each parent)
1. Married (Iirst marriage)
2. Remarried
3. Separated
4. Divorced
5. Widowed
6. Other (please specifs:)
Father
1. Married (first marriage)
2. Remarried
3. Separaled
-4. Divorced
5. Widowed
6. Other (please specify)

10. What are the education levels of your parents? (Girde number for each parent)
Mother
1. Some high school
2. High scbool degree
3. Vocational/rechnical school
4. Some college
5. Bachelor's degree
6. Some graduate credits
7. Master's degree
8. Doctoral degree

Father

1. Some high school

2. High school degree

3. Vocalionalrochnical school

4. Some college

5. Bachelor's degree

6. Some graduale credits

7. Master's degree

8. Doctoral degree

11. What was the approximate income of your family last year?
1. Less Than $\$ 20,000$
2. $\$ 20,00-\$ 29,000$
3. $\$ 30,000 \cdot \$ 39,999$
4. $\$ 40,000 \cdot \$ 49,999$
5. $\$ \$ 0,000 \cdot \$ 59,999$

$\begin{array}{ll}\text { 6. } & \$ 60.000-\$ 69.999 \\ 7 . & \$ 50.000-\$ 79.999 \\ \text { 8. } & \$ 80.000-\$ 89.999 \\ 9 . & \$ 90.000-\$ 99.999 \\ \text { 10. } & 5100,000 \text { Or More }\end{array}$ 
APPENDIX D

CORRESPONDENCE

$-63-$ 
May 1, 1987

\section{Dear Student:}

You have been selected, at random, from the freshman undergraduates living in dormitories at Virginia Tech to participate in an important study that will represent university students as a whole. This study is designed to find out more about student attitudes and behaviors in regard to dating relationships. Your answers will help develop an understanding of how these issues affect today's college students. Please take the opportunity to make this a successful research project.

You may be aware that research studies involving students are quite common. However, many studies conveniently choose students from specific courses or only obtain volunteers. both of these methods result in a limited view of university students. This study is different. You have been randomly selected so that a realistic portrayal of university women and men is possible.

You may be sensitive to the fact that some of the questions are personal and private. We hope that you will share these important aspects of yourself in order to insure that the results depict a sincere and correct picture of college students. Your responses will be recorded by the questionnaire number located on your study booklet. However, your name and identifying information will NEVER be linked to your response in reporting the data. The research findings will report group trends and not individual responses. All your answers will be held in STRICT CONFIDENCE. Please take the time, now, to complete the enclosed questionnaire.

If you have any questions or concerns regarding this research project, please call the number below. After you complete the questionnaire, put it in the stamped, return envelope and mail it back. Your cooperation is greatly appreciated and we extend, in advance, thanks for your time, effort, and openness.

Sincerely yours,

Joann Schladale

Project Director 
Dear Student:

Last week a questionnaire asking about your dating relationships was mailed to you. If you have already completed and returned the questionnaire, please accept our sincere thanks. If not, please do so as soon as possible. Because this project involves a small, but representative, sample of Virginia Tech students, it is extremely important that YOUR questionnaire be included in the study if the results arc to accurately reflect the attitudes and behavior of college men and women.

If by chance you did not receive the questionnaire, or it was misplaced, please call

(evenings and weekends) and we will put another one in the mail for you. Thank you for making this a successful research project.

Sincerely yours,

Joann Schladale

Project Director 
May 15, 1987

\section{Dear Student:}

You were recently contacted about participating in the Dating Relationship Research Project here at Virginia Tech. We want you to know that each response is extremely important to the success of the study. If we have not received your response, we hope you will take the time to complete and return the questionnaire.

The large number of questionnaires returned is very encouraging. However, our ability to correctly describe college students feelings about dating relationships depends on you. You may have different, yet equally important, perspectives than those who have already returned the questionnaire. Your unique contribution to this study is critical.

In the event that you did not receive a questionnaire, or it was misplaced, please call the number below (evenings and weekends) and we will put another one in the mail to you. Also, if you have any questions or concerns regarding this research project, please call. We would be happy to talk with you. We understand your need for privacy and assure you of complete confidentiality.

Your cooperation is greatly appreciated.

Sincerely yours,

Joann Schladale

Project Director 
May 28, 1987

Dear Student:

Spring is here, finals are approaching, and we know your time is limited; however, we are depending upon you to guarantee a successful outcome for the Dating Relationship Research Project.

Dating relationships are undergoing changes from the traditional image that we have grown up with. Young people are now dating for longer periods before marriage and are facing different issues and decisions than previously. This project is one of only a few studies addressing this topic and your response will provide valuable information.

We have enclosed a questionnaire and ask that you return it at your earliest convenience. Each response is vital and we appreciate your consideration.

Sincerely yours,

Joann Schladale

Project Director 
APPENDIX E

SUPPLEMENTARY TABLES

$-63-$ 
TABLE 6

Pactor Analysis of Coping Items

Pactor Item Denial/Distancing

Loading

1

24 don't let it get to me; refuse to

think too much about it

9 go on as if nothing had happened

27 make light of the situation; refuse

to get too serious about it

31 accept it, since nothing can be done

wiat to see what will happen

.56

4

understand that time will make a

difference; the only thing to do is wait .54

10

try to keep my feelings to myself

turn to school or a substitute activity

just concentrate on what I have to do next

Accepting Responsibility

wish that I could change what had happened or how I feel

vow to change something about myself

22 change something so things will turn out all right

make a promise to myself that things will be different next time 
39 try to see things from my partner's point of view

30 come up with a couple of different solutions to the problem

18 let my feelings out somehow

17 make a plan of action and follow it

2 try to analyze the situation in order to understand it better

41 exercise to relieve tension

40 remind myself that things could be worse

38 go over in my mind what I will say or do

12 express anger to my partner about how I feel

5 try to get my partner to change

Social Support

25 ask a relative or friend I respect for advice

13 get sympathy and understanding from someone else

14. tell myself things that help me to feel better 


\begin{tabular}{|c|c|c|c|}
\hline \multirow{5}{*}{$\begin{array}{l}\text { Pactor } \\
6\end{array}$} & & Spiritual Belief/Pantasy & \\
\hline & 36 & pray & .61 \\
\hline & 37 & prepare myself for the worst & .54 \\
\hline & 34 & $\begin{array}{l}\text { daydream or imagine a better time in } \\
\text { our relationship }\end{array}$ & .50 \\
\hline & 8 & $\begin{array}{l}\text { hope a miracle will happen to solve } \\
\text { everything }\end{array}$ & .45 \\
\hline \multirow{3}{*}{$\underset{7}{\text { Pactor }}$} & & Self-Control & \\
\hline & 7 & don't do anything I might regret & .65 \\
\hline & 21 & try not to act too hastily & .60 \\
\hline \multirow{4}{*}{$\begin{array}{c}\text { Pactor } \\
8\end{array}$} & & Escape/Avoidance & \\
\hline & 23 & avoid being around other people & .68 \\
\hline & 11 & sleep more than usual & .66 \\
\hline & 26 & keep others from knowing how bad things are & .34 \\
\hline
\end{tabular}


TABLE 7

Pactor Analysis of Negotiation Items

Item

Loading

Pactor 1: Negative Affect

16 be especially disagreeable $\quad .82$

15 withdraw; become cold silent .75

18 insult or swear at $\quad .75$

17 discuss the issue heatedly .74

19 leave the room, house, etc. $\quad .56$

13 do some fast talking .49

Pactor 2: Direct Appeal

2 try to persuade $\quad .80$

2 simply ask for what I want or need $\quad .67$

1 repeatedly make my pont until he/she gives in .60

4 use logic reason; give all the reasons

Pactor 3: Bargain/Compromise

8 talk about it; discuss our differences and

12 needs

compromise $\quad .76$

Pactor 4: Dltimate Effort

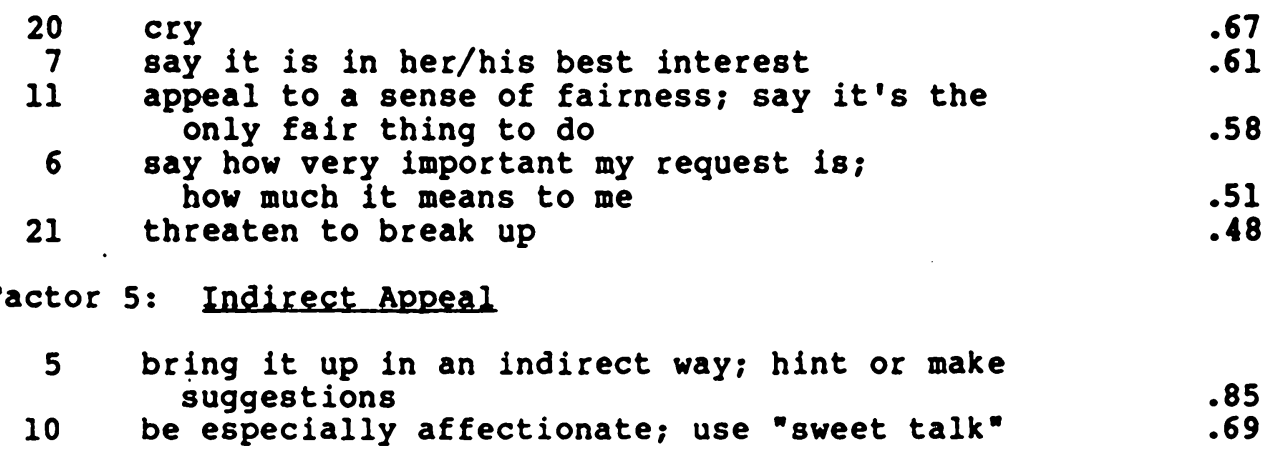




\section{The vita has been removed from the scanned document}

